University of Louisville

ThinkIR: The University of Louisville's Institutional Repository

Electronic Theses and Dissertations

1939

\title{
An investigation of methods for quantitative spectrographic analysis.
}

Frederick Bertram Johnston

University of Louisville

Follow this and additional works at: https://ir.library.louisville.edu/etd

Part of the Chemical Engineering Commons

\section{Recommended Citation}

Johnston, Frederick Bertram, "An investigation of methods for quantitative spectrographic analysis." (1939). Electronic Theses and Dissertations. Paper 1807.

https://doi.org/10.18297/etd/1807

This Master's Thesis is brought to you for free and open access by ThinkIR: The University of Louisville's Institutional Repository. It has been accepted for inclusion in Electronic Theses and Dissertations by an authorized administrator of ThinkIR: The University of Louisville's Institutional Repository. This title appears here courtesy of the author, who has retained all other copyrights. For more information, please contact thinkir@louisville.edu. 


\title{
UNIVERSTTY OF LOUISVIJIE
}

AN INVESTIGATION OF GWTHODS POR GUNITITID "

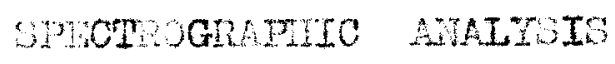

\author{
A Dissertation \\ Submitted to the Foculty \\ of the Graduate School of the University of Louisville \\ In Partial Iulfillinent of the \\ Requirements for the jegree of \\ WABTIR OF CHINICAL GNGINEERING
}

Department of Chemicel Ingineering

By

Frederick Bertram Johnston 


$$
\text { Frederiok Bertran Johnston }
$$

AN INVBYIGATION OF IMTHONS FOR OURMIDATTVE SPIBTROGRAPHT AIULXSIS

Approved by Lxanination Comenttee

$$
\text { Director : }
$$

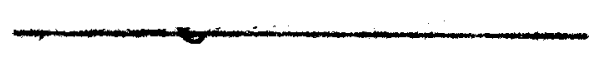

Approved for Inglish

$$
\text { June } 0,1939
$$


RABLE OF CONPENTS

Page

Iist of Tables

ii

List of Figures

iii

List of Definitions

$i \mathrm{~T}$

Acknowledgement

v

Introduction

1

Historloal

3

Theory

Apparatus

24

Procedure

37

Data

54

Results

70

Summary

105

Bibliography

174 
LIST OF TADLAS

TABL

Page

I

Hxpoctod Range of Grain Ash Analysis

II

Composition of the "Average Ash"

III Compostion of the standard ilixtures

$\mathrm{K}_{2} \mathrm{O}$ Varied

$\mathrm{Na}_{2} \mathrm{O}$ Varied

57

CaO Varied

Lgo Taried

$\mathrm{Fe}_{2} \mathrm{O}_{3}$ Varied

$\mathrm{P}_{2} \mathrm{O}_{5}$ Varled

IV Gravinetric and Volumetric Factors

Amounts of Internal standerd and Diluent

Substance Mdded to Standard Ialxtures

VI

Spectrum Iines Recomended in the ifterature for uantitative Anolysis

VII Coordinates of Jperating curves

VIII Results of Spectrograhic Analysis of corn Ash

IX Calculated Composition of Corn Ash 
LIST OE FIGURES

Figure

Page

1 Spectrograph and Rowland Circle

2 Spectrograph and Logarithmic Sector

3 Optical System and Arc

$4 \quad$ Electrionl Circuit

5 ualitative Spectrograms

6 Representative uantitative Spectrogran

7 Effect of Duration of Dxposure and Developnent Time on puality of spectrograms

8 Anelytical curves $\mathrm{K}_{2} \mathrm{O}$

9 Analytical Curres $\mathrm{Na}_{2} \mathrm{O}$

10 Analytical Curves cao

11 Analytical curves 1 higo

12 Analytical curves $\mathrm{Fe}_{2} \mathrm{O}_{3}$

13 Analytical curres $\mathrm{P}_{2} \mathrm{O}_{5}$

14 Ratio euantitative Curves $\mathrm{K}_{2} \mathrm{O} / \mathrm{6aO}$

15 Rat1o guantitative Curves $K_{g} 0 /$ Mgo 94

16 Rat1o iuantitative Gurves $\mathrm{Na}_{2} 0 / \mathrm{CaO} 95$

17 Ratio uantitative Curres $\mathrm{Na}_{2} \mathrm{O} / \mathrm{Mg0} 06$

18 Ratio euantitative Curves GaO / MgO 97

19 Ratio uantitative Curves $\mathrm{MgO} / \mathrm{CaO}$

20 Ratio cuantitative curres $\mathrm{Fe}_{2} \mathrm{O}_{3} / \mathrm{CaO}$

21 Ratio uantitative Gurves $\mathrm{Fe}_{2} \mathrm{O}_{3} / \mathrm{HgO} 200$

22 Rotio uantitative curves $\mathrm{P}_{8} \mathrm{O}_{5} /$ CaO 101

23 Ratio uantitative curves $\mathrm{P}_{2} \mathrm{O}_{5} / \mathrm{Ing} 0 \mathrm{I0}$ 

ard Mixture.

IF Remainder in Standard Mijxture Roneinder in Average Ash ; oxtale in Average Ash $\mathrm{x} F=8 \mathrm{~F}$ ide in standard Mixture.

$x \quad$ Buivalent elght of Roagent Equiralent height of oxide ; The term "equivilent weight" used hore signifies grams per gram atom of the element. I Reciprocal of the nuraber of $m$. of solution containing 0.1 gram of an oxide. $\Delta L \quad$ Difference of lengths of spectral lines in a "Ilne pair". Units $=1 / 32$ inch on riln. * Indicates a secondary surce of reference. 
The author of this thesis achnomledges the kind aid and helpful sugeestions of i2. D.E. Liticenhous, who directed this research. 
2

INWWOUOLTON 
During the past fev years the spectrograph has beoome recognized as an excellent moans for quantitative nalysis. Its most useful application has been the rapid deternination of minute quantities of certain constituents and impurities which determine the physical and chemio 1 properties of ver ous materials. The minor constituents of metals, alloys, soils, precipitates, solutions, and plant and animal tissues have been estimated by quantit tive spectral anelysis. Very little emphasis, hovever, has been placed upon estination of the major components of any substance by this means.

A repid, econorical, and fairly accurate means for determination of predominant mineral elenents of raw materials would be very desirable in the processine industries. The practical inportance of such 8 nethod has been discussed by Shipman (25) in a study of the effect of inorgenic compounds in prain ferment tions.

It is the primary purpose of this research to investigate methods for guntitative spectrographic analysis. 'The secondary objective is to investigate the applieability of these methods to the quantitative spectral nalysis of the najor mineral constituents of grein. These are potassiun, sodiun, magnesium, calciun, iron, silicon, and phosphorus. 
IISPOITCA 
Sir Isaac Newton might truly be oalled the father of spectroscopy. Although the law of refraction vas dis covered by snell in 1621, the fact that different vaveIengths of light are refracted by different anounta was unnoticed until 1666. It was in that year Newton found that white light inoident upon a prism is dispersed into a colored spectinu. Later he used a sit in his experiments, but it was Iraunhofer who developed the complete spectroscope when he introduced the use of the telescope for visual exemination.

raunhofer observed the phen menon of the absorption lines characteristic of the solar spectrum, and in 1814 published results mappine 700 of them. Shortly afterwards, it was learned that these absorption lines appear at wave-lengths corres onding to goetral emission lines of know elements. Bunsen and Kirchoff pioneerod an investi gation to establish the constituent elements of the sun, and lald a foundation for the entire science of spectroscopic enalysis. These men were probably the first to establich the fact that each element has its own aistinctive spectrum. A fev years later luggens and Miller commenced similar work on the stars.

The first true efforts to use the spectroneter for quantitative analysis were made by Haxtley $(20)^{*}(26)^{*}$, 
who atterpted to utilize the progressive disappearence of pectral Iines of elements with decrease of their concentrations in the source. By 188: he had investigated the proportions of certain metals which would be evidenced in corpounds by the presence of their lines in the spectrum. Pollok and Leonard $(26)^{*}$, using the condensed sparl spectra of metallic silt solutions, continued liertley's work. With a guartz spectrograph they were able to show the degree of persistence of the spectral lines as the quantity of a netal. in the sample vas reauced.

Thus Hartley and his co-vorkers latd the basis for a nethod of approzimate quantitative apectral malysis wich has been froquenty used to the present time in mineralogical and other analyses.

working on the spark spoctr of solids such as rinerals, alloys, and fused gelts, de cranont $(20)^{*}$ found thet th: porsistent lines vero not almays the strongest in the spectrum of a metal, that they are actually arc lines, but are prosent in the spectra of hot flanes. The methods in most comion use today are rnodiflcations of that of de Gramont, consisting of the visual comparison of a spectroeram of the specimen with a sories of spectrograms prevjously prepaxed from standards of known composition. 
Itchie (20) eliminated the objection of duplicating the so-oelled standard conditions by photographing the spectra of the standards in juxtaposition to the spectrum of the unknown for each deternination. Whis overcane veriations in exposure and development.

Another great advanoe has been described by frorlach and schweitzer in "Foundations and Iethods of Chemioal Analysis by the Hassion Spectrum ". This was a sinple nethod devised to elininate small deviations in routine and fluctuations of the source. The intensity of the sectral Ines of the uninown tas equated or compared for various percentage compositions with lines of the base substance, or some forelgn ubstance purposely introduced in known anount. This is now generally known as the "Internal Standard hethod " of Gerlach.

Droins on and $\operatorname{van}$ Someren (26)* employed the method of Gerlach in estimation of aluminum, iron, niokel, lead, mangenese, and tin in brass, and sinilar minor constituents in lead alloys. A compreiengive survey of their applioation of the spectrograph to this field of analysis was published in 1931. At the same time, Ranage $(26)^{*}$ and his collaborators used the nethods of de ranont for serniquantitative analysis of elenents in animal tissue. 
The diffialty of finding suitably spaced "homologous-" or "comparison lines" then using the internel standard method was neatly overcone by sheibe and Neuhausser (26)* in 1928. Meir method involved use of the logarithinto wedge sector to measure the relative intensities of the two homologous lines, rather than merely noting their equality. iryman and Simeon (31) made subsecuent molifications and inprovement on this nethod, and Lyman and Fitch (31) Introduced the occular micrometer for measurement of the len ths of lines in a homologous pair.

Thyman and klervey (26)* have successfully employed the sector for extration of chromiun, manganese, and njekel in steels, ustrg an are between two specinens of the test sample. In England, Sinith $(26)$ has performed extensive investigations for aplication of those methods to the testing of commercial products for conformity to speciincetions.

Iruing the past ten years, literature has disclosed the developinent of a ereat number of other nethods for quantitative apectral an lysis, but these heve simply been modifications or combinations of those alrady described. The trend has been for the applications of spectrogrephic analysis to become nore numerous and aiverse, and toward improved technicue to secure greater ecouracy. 
When a substance is sufficiently excited, or brought to a very high energJ level by volatilization in an electric arc, there results a characteristic emission spectrun. The discontinuous spectrum of the aro proper, arising from the Iuninous flame containing vapors of caxbon and its compounds, is visible, and a number of narrow Iines caused by rapors of the metals present appear. Violet bands are produced by cyanogen, formed by combination of the carbon and nitrogen of the eir, and $B$ ite the are its characteristic color. In the are, all the netals and carbon, silicon, boron, phoshorus, and arsenic yield characteristic spectra.

If pure element or mixture is arced to produce a spoctum, a number of lines of varled intensity appear. If that element is ailuted with other ele cents or materials, the original spectrum lines decrease in both lutensity and number. Upon further dilution the weakest lines disappear, the stronger lines grow weaker, act at the lowest concentration at which the elenent can be detectod there remein only the rajes ulcimes or persistent lines. since under lite oonditions of excitation and observation a given concentration of an elenent yields the same intensity for the sane lines, quantitative analyses con be made by comparing the number and intensities of the lines of 
those elements beine deternined with a series of reference standards.

whus the basis of quentitative spectral anelysis is that under the sene conditions of experinent the intensities of the spectral linos of an elenent in a substance are functions of its quantity in that substance. The modifying conditions are the method of excitation, -whether flane, spark, or are, the intensity of that crcitation, the electricel potential, and the influence or other constituent elenents. Where are also the fretors introduced in the photographle process, such as the optical system used, the bypo of filu erployed, the width of the spectroGrophic slit, and nethod and tine of ievelopment.

Athough it is impossible to prodict the line intensity mich vill correspond to given concentration of an element in a material, for any fixed set of conditions, reliable correlations can be obtainel between intensities of lines of several constituents and their percentages. Wis is nost rully realized when these factors are taken in relation to those of a dominant elment. The lines to be compred should bo chosen close together in the spectmun, and if a nurber of elements are to be estinated from a sinele spectrogram, 011 the solected Ine: incluaing those of the struard, ahould lio in a 
region of constent or slowly varylng oontrest of the photoprephio film. This is doternined proctically by a vicual

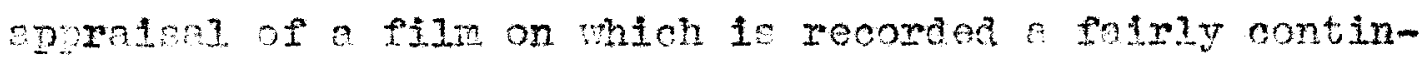
uove sectmu, suoh as that of iron.

plate bockound offers some difficulty, and fev oxroctions seem reliable, so that it is better to arrange the expocure to minimuze tts anount. Sone expertnenters nov mantanes that e certain amount of beckrround is conirable to brin the fainter lines over the "threshold of sensitivity" of tho silm. Also it is imortent to time the exponurcs on that blackening of the more intense lines do not exceat the maximu bleckenthe obteineble on the film. Then an element ocoure in considerable amonts in the emple, thore is apt to be reversal of some of its Iines, so thet trose Innes with ore not readily absorbed should be chose. It is possible for this reversel to produce a wakening of the whole line wen the obsorption is

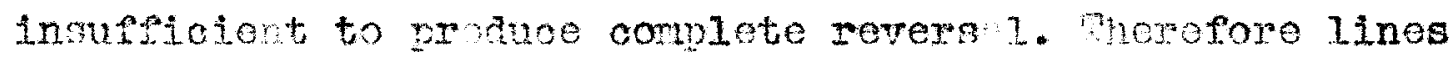
can be found for an olement prosent in vigh conoentrntion Wich appear veater then in the spectrun of the cane element, st considorably Iover conventration.

In the uevel annlysis, a mixture of cevoral alements is boing exmined, and the relative intensities of tho lines frequently chow wae rariotione becase none lines 
are strongly affected by the presence of even sall knounts of another. The lines enoson should be tosted for such erpects. All estinates should bo basod on tho voakot lines that are clearly derinad, and on bhose which very nost rapialy with change in oneentration of the element. There is no linit to tho concentrotion at wich elenonts can be determino spoctrographically, but the errowe of estination are proportionally large.

The retio of line lutengitios changes quits sowIy ith change in aro curront above e certain anount, and the ratio becones ingensitive to such fluctuations as exist in a nomal arc.

The are is preforablo to the spars because it is quicker, woro convonient, and is peirly acourete. It possesses groabea sensitivity beause of the hich temperabues of the electrodeg, and tho resultant density and concentration of the vapors ovolved.

tho types of spocianon tested are videly variant. in uetallurgict analysis, piocos of notals to bo tested have served as the electrodes, and a curront of apores has proved subicient to produce an aro revedine all of the constituents present. rery shall piecos of lietal or other samles, such as powaers, prociritates, or posidues from solutions can be exa ined by aroine from th tho 
cevity of a lower carbon electrode. Refractory materials such as solls must be volatilized by use of high ampereage, which inoreases the sensitivity of the arc. It is sometimes convenient to dissolve the semple and to spectrograph the solution, elther as a resldue formed by craporating a few arops of lt on a hot electrode, or as a spray blown between the carbons. However, this latter is permissible only with the spark.

lant and animal tlssues can be sparked for spectral analysis, but the general preotice has beon to redwee these to an ash. A vegetable ash contains carbongtes, ohlorides, phosphates, and silioates in unknown proportions, the ratlo of these varying according to the method of ashing the particular sample. However, the relative anounts of the minor metall1o constituents and some major element will remain unchanged regardjess of the treatment.

In order to avola volatilization of phosphorus, argenlc. tin, and other elements during the ashing, the sample mat be nolstened with conoentrated nitrio acid, and as the orgenlc materlal burns off, It must be cooled and renitrated. It 18 desirable to ellninate all carbon before spectrographing. Then this is oompleted, the addition of a sllght excess of sulfurle acid serves to reduce all of the metellic constituents to the common basis of 
the sulfete. Thus, after the exceas sulfuris acld has been driven off by evaporation and gentle Lenition, the mass 18 in a condition approximating normal oulfatos, homogeneously mixod with pre-exietinc phosphates, silice, and chlorides. If this ash is then mixed with an equal weight of spoctroscopically pure anmonium sulfete, there is supplied in effeet a constant amount of sulfuric acld, the mass is rendered more porous, and the eation of the arc is more regularized.

Some suoeess has attended the preparation of manll eleotrodes of plant naterials by compression, followed by carbonization.

The queation of the effect of the anions present In a bample lumediately ax1sos. Tourtellette and Rask (30) heve determined that the number end Intensity of aluminum Ines are due entirely to the concentration of that element in the speotral source and is independent of the attached radieals. Duffendack, Mley, and ovens (6) found, however, that the oulfates and phosphate radioels docreased the relative intensitios of the lines of all the elements studied ( $\mathrm{Ne}, \mathrm{K}, \mathrm{Al} G$, and $\mathrm{Ca}$ ) vith respect to those of cedulum, and that the chloride Ion onhanced the intensities of those Ines without appreciably changing their relative intensities. 
Sodium, potassiun, an magnesium have been found to decrease the relative intensities of the spectral lines of each other vith respect to those of cadnium (6). The amount of these effect increases with increase in concentration of the aisturbing element, but reaches an approxinctely constant value et relatively high concentrations. Chlorides glve low temperature arcs because of their comparatively high volatility, and as a consequence the ares are not very sensitive. Nitretes are unstable in the arc. ulfates aro the most desirable form as they give a nigh texperature are, are easily prepared, and since they do not absorb atmospheric molsture, nay easily be handled in the powdered Porm.

Ninally, the various factors involved in the photographic procoss should be considered.

The sharpness of the end-points of the lines can be enhanced by adjusting the spectrograph to critionl focus, developin the plates to maximm controst vithout fog, and lacing the aro es far from the sitt as poasible and the sector disk as close as possible. The density of the background is ade negligible in comparison with that of the spectral lines in the ame operation. Graphte olectrodes are preforable to conper because of tine groater sensitivity resulting pertiy from the 
nigher temperature attained and piatly from their geater reducing power. Carbon electrodes are generally chosen because of their lower price, ease of coring an washing after use, comperatively steadj burnin, and extrenely sensitive soetrm erolved. 


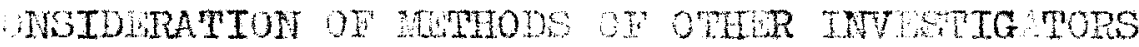

In the development of the method of spectrel nalysis used in this research, all previous methods were given critical consideration.

It has been previously mentioned the the intensities of the spectral lines of elements are approzimately proportional to the respective anounts of those elenents in the sample. The determination of the anount of any elenent, then, hes depended upon the moasurement of the inten sities of those lines, in compariton with standards of known and controlioble intensities. The comparison has been effectel in a number of rays.

De Gramont simply compared the spectrura of the somple with a series of sectra previously prepered from sinilar sainples of known but varying content. An approxinate estimation of the amount of any constituent in the specimen wo the: made by notohing the sample spectra with respect to the intensities of the lines of the elo ents in question.

A refinement of this method vas introduced by Nitchie (20). Differences caused by variation in potoeraphic material and develoment were largely eltminated by photographing the spectmum of the unknom in juxtoposi- 
tion to the spectra of the standards. These vrere a graded series of mixtures of composition sinilar to that expected In the unknom. To avold unnecessary expenditure of tine, the perticular stondarda to be used with the sample were selected by a prelfrinary test. The approxtmetely correct value was then $f$ und by comparison whth three successive standards. Of these, one contained the anount of the elemont prolloted from the prelininery test, another slightly nore than that conoentration, and a third slightly less then that anount. Hitchie emphasized the importanoe of using the weakest lines that are clearly defined, to avold possible error caused by reversel. He began the practioe of using complex gtandards for the purpose of determining several constituents simultaneously.

Probably the best technique yet developed was that of the Internal standard method of Cerlach and Sohweltzer. The Ilnes to be determined were compared with the lines of another constituent in the same spectrun. This reference elenent was present in bnom or at least controllable amounts in every sarple. The partioular advantago galned was that, if for uncontrollable reasons a variation of conditions occurred, both the Iines of the constituent to bo deterinined and the lines of the reference tandard were affected to the sane extent and their ratios remalnod 
essentially the same. Neturally a preliminary celibration vas recuisito, basod on similar necsurenents of pectra from the series of standerd semples.

Thus all of the constituents present in staller anounts were detemined reletive to the main constituent. $\therefore$ hypothetical example vould be the determination of iron, kluatnum, monesium, and copper in water. If a mineral residue vere obtained by eva oration of a given volume of Matez, stirred the inlle to insure homogeneity of the somple, all those elements could bo determined rolotive to the calciun prosent. This ould tiren be easily determinablo chenically as perts per million of the woter. buffendack and wolfe (7) obtoined excellent results in the cnalysis of caustio liquors for traces of netallie imurities, using es the intomal standard a amall anount of sodium inolybdate. The molybdenum turnished spootral Ines suficiently close to those of the test elenent: to serve es the intermal control for all, and the lines selected were wh that analysis could be made for 211 tho tast elements from a single exposure.

sinilarly, an acurate neens for the determinstion of menesium, oelotu, sodiun, on potassiun relotive to ondniun hes been develope. for urinalysio $(0)$. 0 eliminato mutul errom. intralued by thoso elunents, the 
investigators omployed the "method of excess". "his in volved sope ation of the olution into pour portions, and addition of an excess amount of the jisturbing elengnts to eaoh portion tested. In any one of the four, an adation of oliminated variution prohuced by any single elonent. This Iod to tho idea that an walysis coula be condvoted on ratatures in which the conoentration of interPering elenents wes sufficiently lerge thet the efrect on the intensity of 211 the other elements remined constant. For the deterination of ninor constituents in lant ash, such as minium or gine, the practice has beon to introduce a small anount or sone olonont poreign to that matorial, such as telluriwn (2) or cadnium (16). In net llogra hio spetrel andysis, a ain constituent us. uelyy served as the intornal otandard, pelative to which vinox constituents or impurities vere detornined 26 ). The necessity of finding suitably spaced homolorous linos for the internal standar nethod ras renoved Dy Schetbe and Hevhaussex $(26)^{*}$, who neasured tho reletive inte sities of the two lines rether than noting their equality. Whis was accomplished by use of the logarithale sector - a thin metel dist tho elge of mich had been out awey in a logarithic curve. hen this was rotated betore the slit of the peotrogron, on intomittent $r$ ridble 
exposure along the length of the dit was secured. Whe uper etion of the alt recoved the nost, and the lower portion thr lenst exposuro to the matation, indopendenty of the into of rotetion.

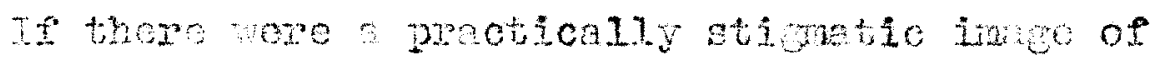
the lit on the film- that is, th onok olenent of the slit

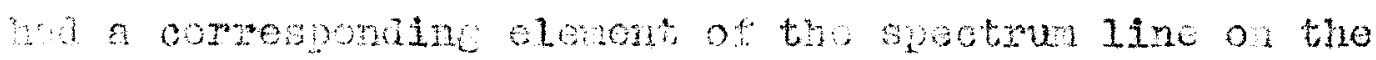
21 to or ein, then the photogrevate blatonine of the

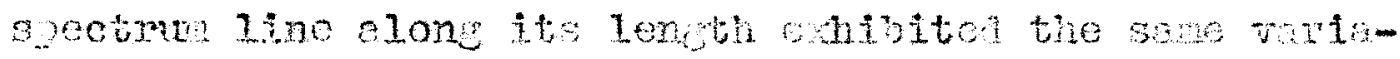

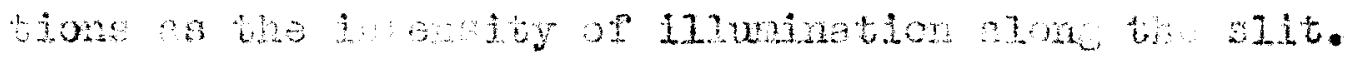

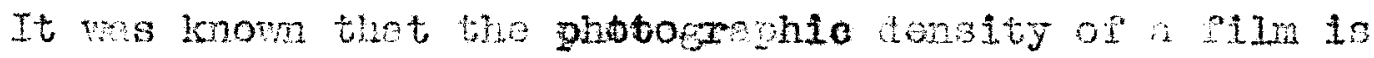

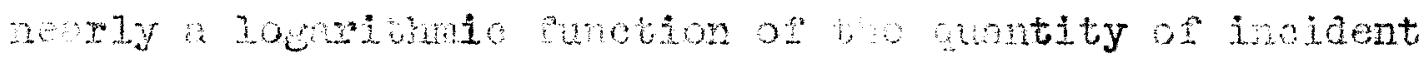
$11 \mathrm{~g}$ or durction of aposure.

The cotor res enproyiotely civer such a form

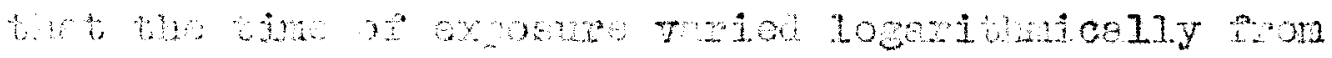
point to polnt of the slt. morefore, the differonos of lensthe of two poctrogrwhie lines wore proptional

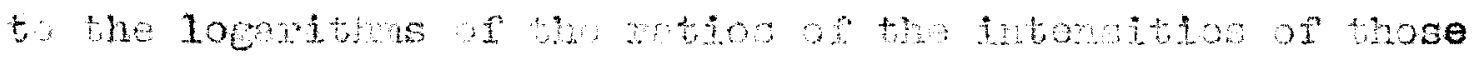

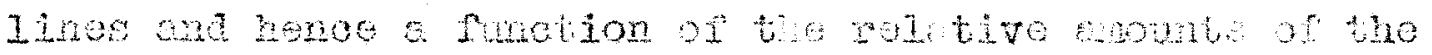
correspontine lewente In pretice, the worting on oporsting curves wero obtaned by plotting the difrerences in

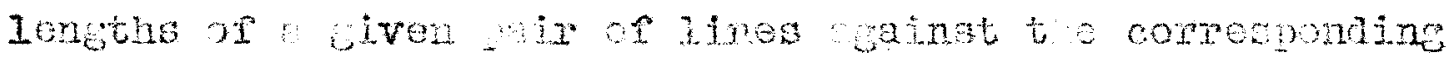
xetios of the anoute of the two eloknts. Providing thet

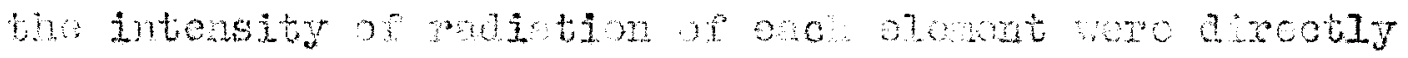


proportional to its amount in the sample, the rolationship was a straight line. For any two elenents, the resultant curves of this lunction have been found to be different for the difforent line-pairs used.

since the exposure ves veriable alone the length of the slit, a graduel tapering-off of the intengity of the linos occurred, and ench had the appearanoe of a long wedge. The determinine factor with regard to the aocuracy obtainible has boen the acuraoy vith wich it was posBible to measure the lengths of those lines. Ihis method has beon applied in a variety of andyses. Iavin (26) and Sullivan (27) independently adapted the use of the sector disk to quantitative determination of oadmium, Iotd, and other constituents in zinc. The former measured the differences in lengths or lines by an occular mimoneter, and the latter with a small oyepiece and sealo. The thoory of the ogarithic sector and its appliodion to quentitative spectral analyais rave been aiscussed by Ivryan and simoon (3I) and fiultgren (15).

or most recent development has been the Rat1o cuantitative systen of judd lowis (17). This was simply a modisication of the intermal standard method, an i.volved use of specially prepared standards. Al the constituents were dotermined in relation to a single on- 
stitucnt, which was preforably a mojor ono, and thich could be deterinlned by chemleal moans. The standards were of Ilke composition to the specinen, so that nodifying effeots of component chemloels upon other elenents vere produced in both. The spectra were therefore strictly comparable as long the conditions of excltation vere maintained constant. An agricultural base, for exmple. has been devised to make nore normal omparisons with vecetable ashes.

Th bese contalns the olements Calclun 10. Yagnesiun 10, Potassiun 35, Sodium 5, Phosphate 35, and $\$ 1110 \mathrm{~s}$ in the proportions given. This can bo furthor modified with small quantities of other elenents such as iron, manganese, eluninum, or zinc. The line of any one of the elenenta caloim, nagnesium, potassium, or sodiun could be used as the standards for comparison.

Ulibourn (19) has recently publlshod a paper on the spootrographio analysis of soll and plant meterials using this method. 


\section{APEARATUS}


The entire ap aratus is shown in Figures $?$ and 3 . pages 27 and 29 , and is described with reference to these illustrations in the following discussion.

The instrument proper consisted of a light-tight trlaneular metal body. supported on three legs. Two of these fitted into a grooved board, onto whlch the optical bench wa bolted, the third leg being free, but supported on a base of equal holght. A loose fitting cover allowed immediate access to all perts. Baffles and soreens within the housing prevented extraneous light from reaching the screen.

The slit, grating, and camera were arranged to GIvo a first order spectru in a "fixed" Rowland mounting. As shown in Figure 1, the camera and grating vere at opposite ends of a dlameter of the Rowland cirole, and the silt was at the $90^{\circ}$ vertex of a right triangle inseribed in the semi-oircle.

The sl1t was made of stainless steel jaws, of which one was movable. One knurled screw outside the body controlled the width of the slit, and the other effected the rotation of the sllt about a line whioh milut be Imagined to exist between the center of the slit and the grating. By this second adjustment the slit opening wes made parallel to the lines of the grating. 


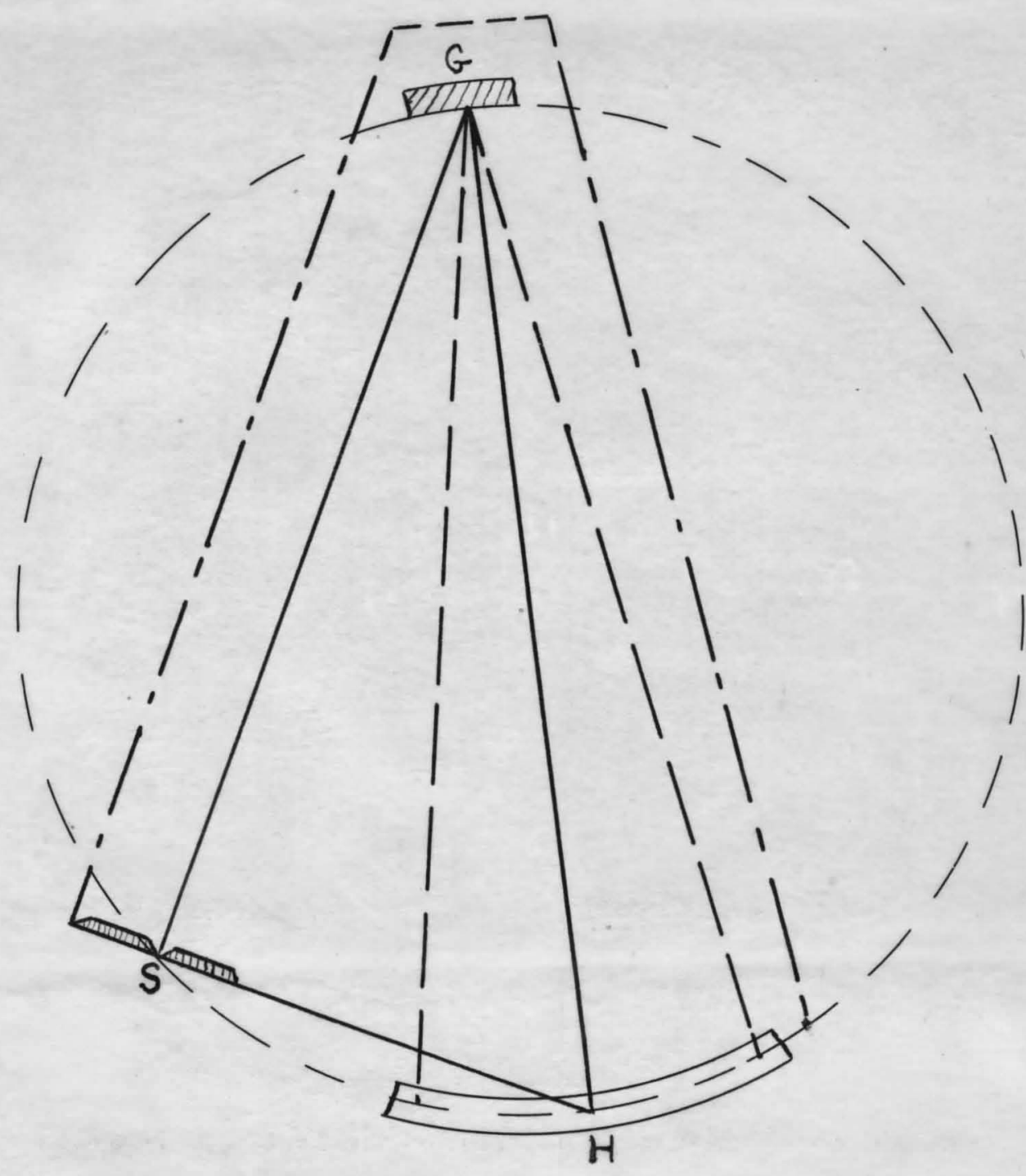

G Grating

H Film Holder

Fig. 1 Spectrograph and Rowland Circle 


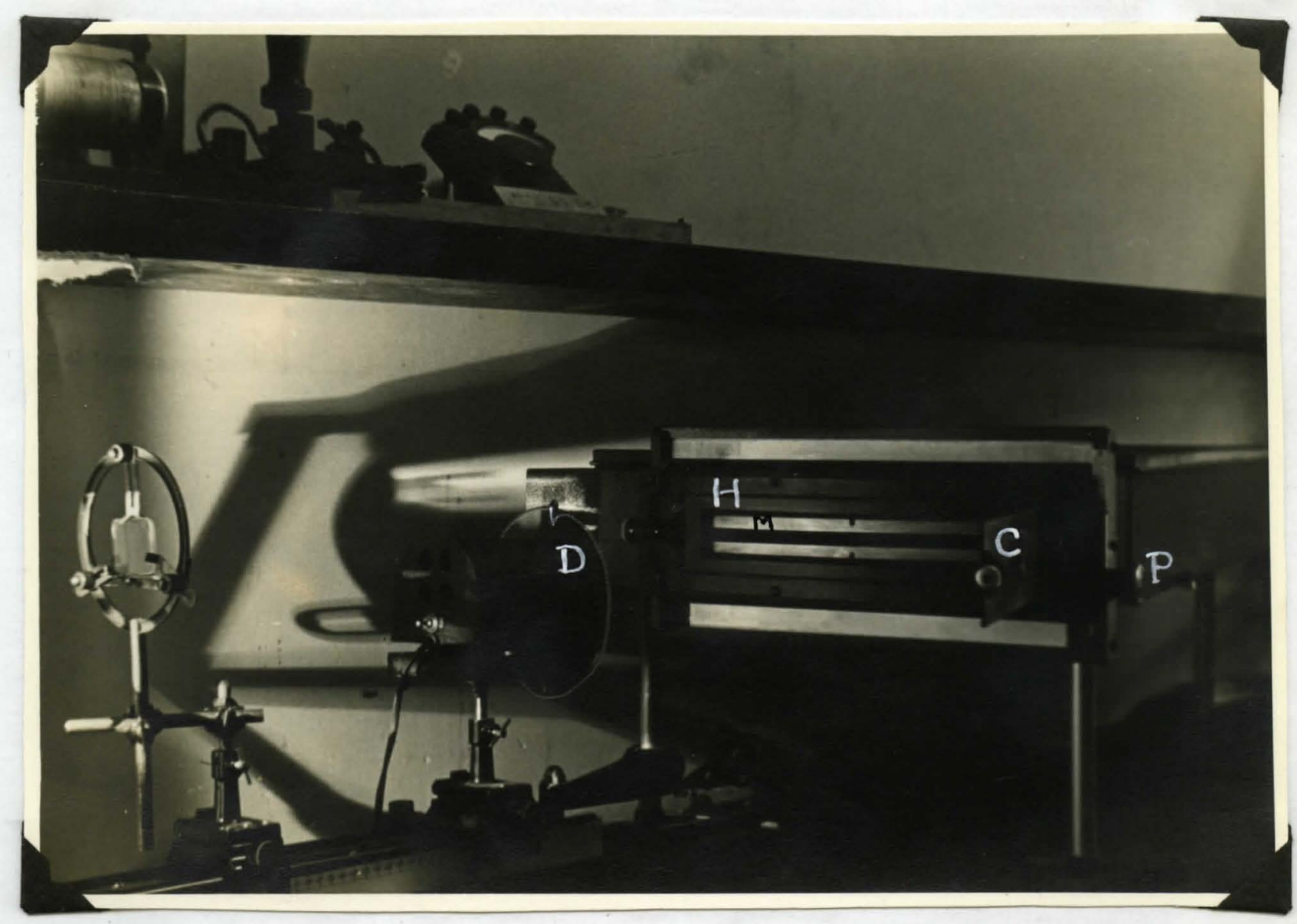

Figure 2. Spectrograph and Logarithmic Sector

C Hinged Cover

D Sector Disk

H Filn Eolder

P Pinion

II Slotted linsk 
A Vallace conoave refleoting repliea grating of $206 \mathrm{om}$. Foel length and 15,000 11 nes per inch wes used to produce the speotrum. Its rediug of curvature was the diameter of the Rovland elrcle. Since the film holder, If, was curved to coinolde with the circle, as shown in Figure 1 , all the spectrum lines were approxinately in foous pon 1 .

The length of the speotrum exposed was $25 \mathrm{~cm}$. and the dispersion of the grating was such that a range of 4000 Angstrom units $\left(A^{\circ}\right)$ was oovered. The region from $2800 \mathrm{~A}^{\circ}$ to $6800 \mathrm{~A}^{\circ}$ was obtained when the gratine was nomal at $4800 \mathrm{~A}^{\circ}$. Normal dispersion with very slight deviation at the ends of the range was obtained.

The greting was rounted in the Grating Holder. This device rested an a track nomal to the center of the film holder. The distance of the grating from the flim could be adjusted by sliding the assembly along this track, and a look serew held it in the final position. The grating could be rotated ebout its opticel exis by two vertlcally counter-acting set-screws. it set-screw at the rear of the holder tilted the grating about a horizontal axis through Ite surface, so that the speotmm was displaced in a vert1cal direotion. Fnother set-sorew rotated the crating about a vertieal axis, so that the spootrum range vas alsplacod along the Rowland circle. 


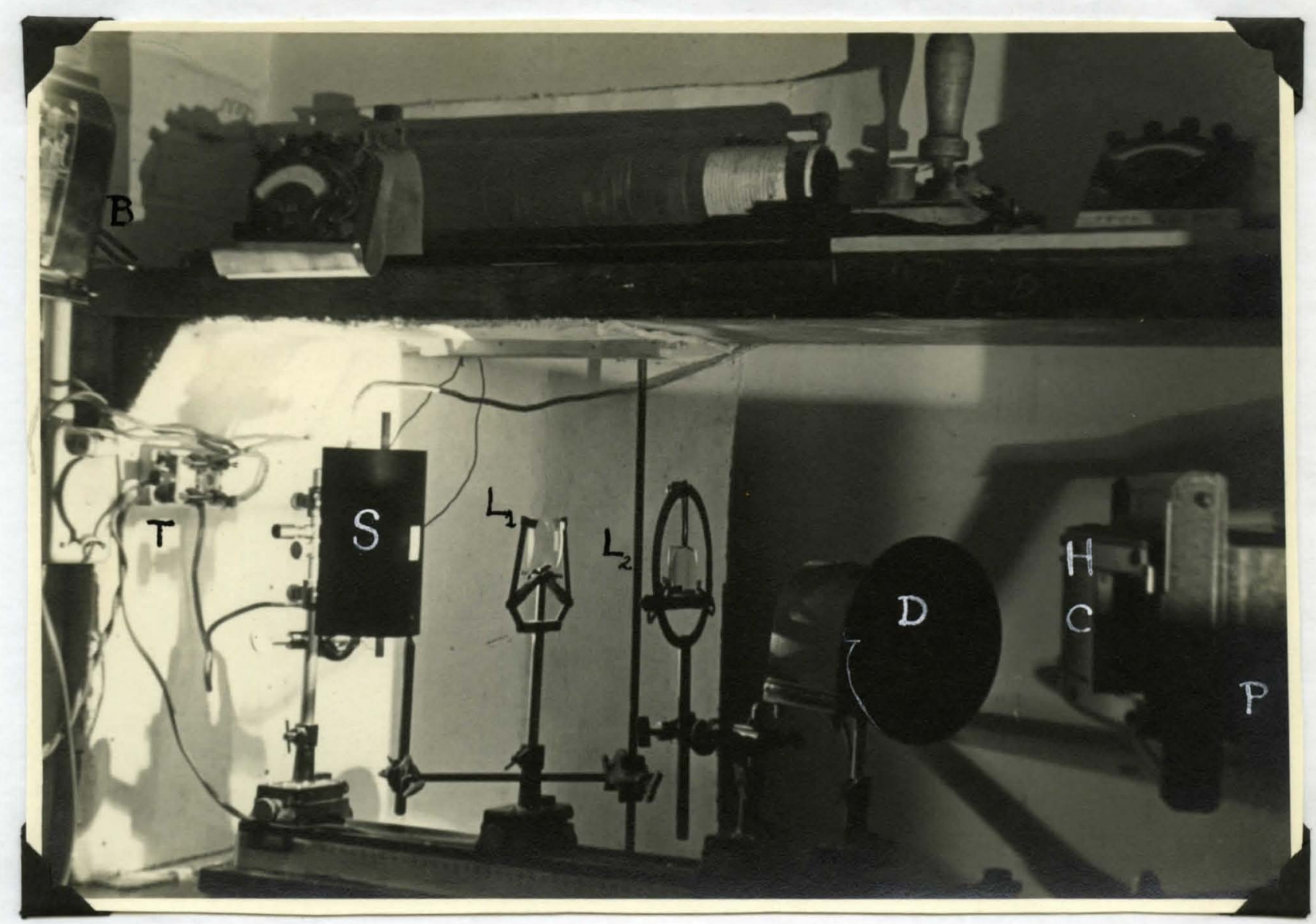

Figure 3. Optical System and Arc

B D.C.Switeh-Box I $I_{1}$ Quartz Lens

c Hinged Cover $I_{2}$ Quartz Lens

D Sector Disk P Pinion

EI Film Holder T A.C.-D.C. Switen 
A mierometer sorew, pessed through a threaded bushine fixed to the rear fece of the housing, provided a sensitive neans for edjustine the position of the grating. The filn holder, F, wes a freme device, slotted on one side to receive a motal slide, and having a hinged cover, $C$, on the other. This holder was removable, and the entire assembly could be shifted rertically by means of a raols and plnion, $P$. This pernitted exposure of adjacont areas then a series of spectrograns was dosliad on a singlo filn. Slotted masks of metal, such as $h$, of differcnt sizes, could be fltted into the camore opening, so that the vidth and nuaber of exposures could be chosen. thaximum number of thirteen spectrograms covld be takon on a single flln, using a steonth-inch slotted mask.

The hinged cover, $c$, attached to the back of the film holder faclittated introduction and removal of the fllms. A strip of oellulold buffod to translusoence with emery paper served as an exoellent viowing scroen. To the richt of the rilm holder wes a socle, and a polntar atteche? to the assembly indicatod its vertioal position. The aro and optical systen supportod in proper aligmment with the spectrograph by means of the lathe type optical track or benoh, $B$, as ghorm in Fiçure 3. one end of this was supported by a leveling screw. 
and the other is linked to an instrument leg by an adjustable arm, shown quite clearly in ifigure 2. The are support consisted a single rod on which two clamps were mounted for holding the upper and lower electrodes in a vertical position. The support rod was clamped onto a non-tilting carriage, which could be moved along the track to any desired position. An indicator rod or alignment pointer (22), mounted on the arc support between the two eleotrode clemps, made possible exact resetting of the arc position preliminary to each exposure. The ends of the electrode clamps, the clectrodes, and the aligmment pointer are visible just outside the edges of the Ilght shield.

The semi-cylindrlcal light shleld, $S$, was mounted indirectly to a fixed support by means of two right-angle clamps and a short rod, shown well in Figure 3. Inis produced in effeat an adjustable universal ooupling by nloh the shield could be easily tilted out of position when are adjustments were being made, and by which it could be shifted in any one of three directions.

The electrical clrcult for the arc has been shown digcramatioaliy in Figure 4. An electrical potential of 250 volts direot current was sup lied by two 125 volt generators in the wlectrical Engineering Labor tory. 
Aternators at the penel board controlled the output voltage of each generator, whioh was set by the individual field rheostats. Behind the panel was the 30 ohm resistor, which provided a constant and major portion of the ciroult load. This wa followed in serles by a transforner primary coll, which acted as an inductance, of about 1 henry ca creity, and added a resistance of approxinately 4 ohms.

At the termination of the conduit was the switohbox and outlet terinals. The negative lead passed to a 12.5 ohn rheostat, of 8 ampere capaolty, by wich the arc current could be varied, thence through the ammeter shunt to the upper electrode. The swltch-box, voltmeter, rhoostat, shunt-plue, and ameter are all show in the upper portion of igure 3. The posftive lead passed through a doublepole-double-throw switch, $T$, to the lower arc electrode. The outer terminals of this switch gave access to 110 volt alternating current for Genera alinnent work.

itwo cylindrioel quartz lonses, deslgnated in itigure 3 by $L_{1}$ and $I_{4}$, were used. The first, $L_{1}$, of 11.5 om. ( 4.5 inch) focal length, was located $14 \mathrm{~cm}$. from the axc, nith the plane feoe toward the aro, and its principal axis horizontal. The function of this lens was to form an 


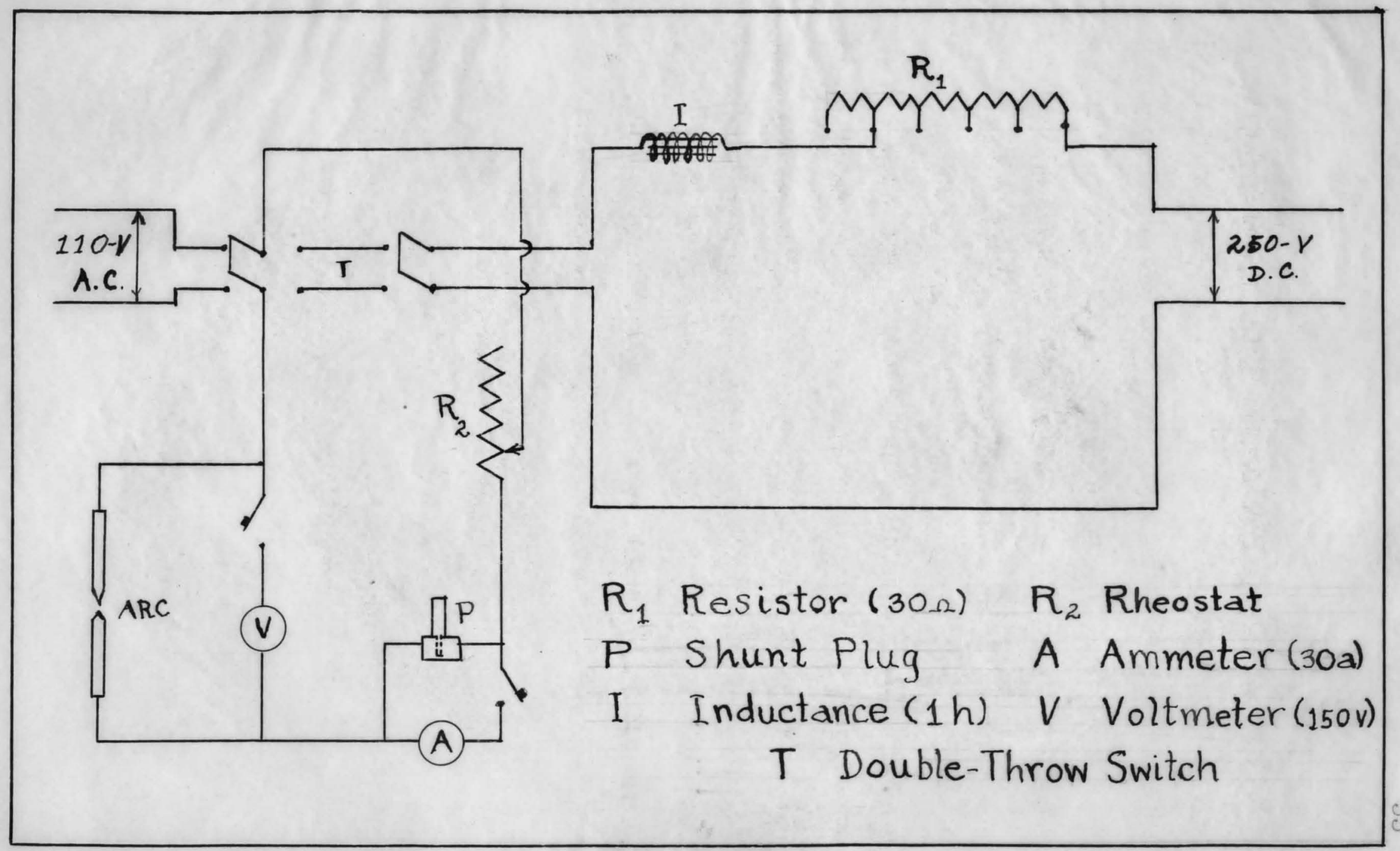

Fig. 4 Electrical Circuit 
enlerged inage of the arc flame on the slit, and consequently on the grating. The second, $\mathrm{L}_{2}$, of $35.5 \mathrm{crin}$. (14 inch) focel longth, was clamped at exactly that distunce from the slit, lane face toward the arc, but principal axis vertieal. This lens served to concentrate a portion of the radiation emorgent from the first as a vertical beam, conrergent on the slit.

The logarithmic sector, $D$, and motor were mounted. on the track next to the spectrograph body, so that the sector disk wes almost flush with the face plate. Ihis position is shown in Figure 2. In rigure 3, the sector and notor exe show displaced from the correct postition, in order that an oblique front view is obteined. The ad justment of this aevioe 111 be described undor the nethof of procedure.

A strin of paper on which a continetior acelo had been printei was attached to the side of the optioel benoh, the zero point feiling directy in the vertical plane of the silt. $n$ end of this senle is vislblo at the botton of each photograph of the instrunent. The positions of all the oomponents of the complete optical system wore then neasur able relative to the plane of the slit.

Both lenses were hold in special clacps, and these were mounted on hinged oarriages so that oither 
could be temporarily and conveniently renoved from the systam. uartz lensea vere necessery to obtein the speotruin in the ultretiolet region.

For gualitative and quantitative woris solld spectrographic carbons of low ash end impurity content vere used. These were oridinelly 6 iuches in lengti, and 3/16 Inch in diameter. For ordinary alfmment work and oxperimental wori, inexpensive curbons of the orthary type were employod. 'inese latter operated an altemating current, whereas the better type requinod direct current. A viewing box allowed oonvenient exmination of the finishod negatives, either wet or dry. This had an inclined window on hioh the fila was placod, ana diffuse indi eet light provided illumination from beneath.

A scale, divided into forticth parts of an inch, and printed on Bristol board, vas used to measure the wave-leneths of the spectrol lines. Since the dispersion of the spectrograph was 4000 Angstrom units oror 10 inches, O1 $400 A^{\circ}$ per inch, each of these divisions was equivalent to $10 \mathrm{AO}^{\circ}$.

An ordinary print box was enlarged for waing prints fron the ten inch negatives. A red buld maintained continuous illunination, and a white bulb was operated by a plunger when the felted lid was closed. At the side 
window was a guide into which a vatter No. 3 Green Filter Was inserted.

$$
\text { whe type of film used was tostman comercial. }
$$

$J-38$, a itbrate perticulary sensitive in the violet and ultroiolet regions. Whe dinenstons were $2,5 / 16$ inch by 11,1/4 inch. Jastman Supersensitive Panchronetic film of the sthe dinensions we used rox the infra-tred photography. DT-50 developes, "hypo" (sodiun thiosulfate), and Azo F, No. 4, single weight, glossy finish print paper wore also used in the photographic processes. Lasise havine slots of $1 / 4$ and $4 / 0$ inch depths served for qualitative and guantitative exposures. 
PROCWDURE 
A spectally grooved support boord was prepared to insure rigid allgment of tho epectrogreph and optioel system. Two of the spectrograph legs were fitted into rubber oups between the two runners forming the edges of the groore, and the third uras supported on a small base of equel height. The optical bench was aonnected to the instrument leg, and securely strapped and bolted to the guide board. These detalls are shown quite well in the two photographic plates.

The are aystom installed at the extrene end. of the optlael treak, with the 2 ight ahleld direotly before 1t. The elrat quartz lens was mounted about 14 an. from the arc, as previously described. Wh the arc operating on a wide gap between the eloctrodes, the helght and positon of the lens were varled until a elear imege of the are flamo wes obtained across the slit. this was an enlarged image of the inner flame of the arc, and had the appearance of a horizontel lavender bend, flanked by the brilliant namow white benda of the hot electrode tips.

Dsing the maxtrum are gap that could be mointained between pure eleotrodes at the currents employed, a more resined adjustment of the lens was made, so that the depth of this bend about 1 inoh. The axe gap, the shleld opening, and the lens were then elevated to corres- 
pond to the holght of the center portion of the slit. iho slit and grating vore next brought into proper sdjustmont. The silt we nidoned ond by means of a small whito card, the path of the ontering benm of light wes followed beok to the grating. The postton of the are relative to the center Ine of tho optien systar was altored guficinntly that the narron vertical inge of the slit appenred directly across the center of the frating. Text, the elevation of the lene and are vere verlod slightIy untal the image of the slit vas symetricol with tho grating in a vertical respect.

To foous the grating this procoduro wes followed: The nounting of the grating was tilted about a horlantal axis until the are speotrim appearod through a wido slotted mask on the viewing screen. Inost any matallic salt in the cavity of the lower electrode prodncod on excellent apectrum for this purpose. The mounting was further tilted until the 11 ne formed by the onds of the speotrol 1 ines was visible. The gratine was then rotated about its optioel axis by the opposing set-serows above it until that Iine of extrone and of tho spootral I Inos was porllel to the slot of the ragl. The lines of the grating were tron at right angles to the longth of the cararn holdor.

1th the slotted mask romorol, the silt was 
rotatod about 1ts axts until the spectral lines beoune vortioal.

Whe desirod ronge of poration wes between $2300 A^{\circ}$ ant $6300 \mathrm{~A}^{\circ}$. A mercury are no betne naileble, the spectrum of noroury. roduced by volitilizing the oxide in the are, vas succesorully used. the groen line et $5461 \Lambda^{\circ}$ was identified by its relation to other lines in the ame speotrua, end the grating rotated abut its vertical axis until this line wes in a position about 2.1 inches or $840 \mathrm{~A}^{\circ}$ from the left edge of the soreen. riv adjutwent was verified by chocking tho postion of the sodiun "D" lines at $5890-$ $5830 \Lambda^{\circ}$.

The spectrom wes then brought into sharp focus by sliding the crating holder along its track by nons of the micrometer screv. ine optiman pasition was selected by clase observation of the rerious lines on the trenslusant screon throuch a reading lens, and this was later chooked by airect observetion vith a sall ejepiece. the assonbly was then secured in potition by tightening the 1oo: screw. The socond lens ves next placed in position, and

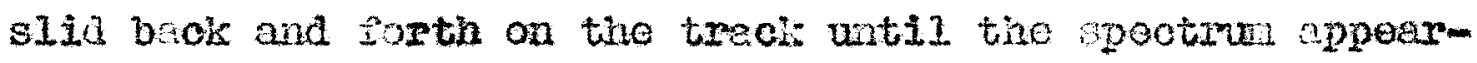
ed brichtast. A chock of its position shored it to be at exactay its fockl. Leagth of $35.5 \mathrm{~cm}$. from the elit. ins caused the entire surface of the gratine to be iliulinated, 
and at the aane time the intensity of iliumination wa increased. The intensity of the lines was enhanced, apparentIy without ineressine the beokgrouna.

The wiath of the sist was then graduaily decreased until the point wes reached at which a further narrowing of the eperture did not change the epperent with of the Iines in the eyepioee, but only reduoed their intensity. bservation of the solum D-ilnes showed the pelr to be resolved into the two components. At this point the lines were sharp and cleorly derlnod, and good resolution had been obtained.

The logarithrile oector was finally mounted directly before the instrument, with the sector disk peralLel to the front faoe, and as close as possible. Ito eleFation was then so edjusted that at meximm masing position there renatnod only a vory narrow brina of the spectron acrose the bottoin of the sask slot. The adjustment of the antire optioal syston wes then such thet the lengthe of the lines rarled apparently just botwen the edges of the nask slat or exposed strip, as the sector tumed. The slot wes 13/ 32 inch in depth.

Wwo preaution lad to be observed. Flrat, great oare bad to be exerclsed not to shut or jam the jaws of the slit, end secondly, oare wes neceasary to avold touching 
the surface of the creting of tightening of the holder to such on extent thet the grating surface would be distoted.

A number of samplos were prepared oorresponalne to an evorage ash. The " average ash" was compoted from tive nean of the upper and lower Iimits of the peroentages

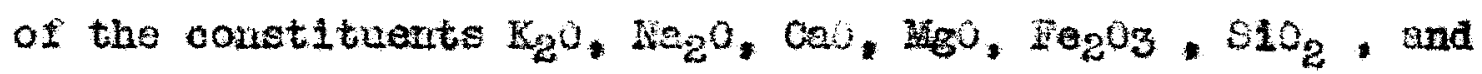
$P_{2} \mathrm{O}_{5}$ deternined in the ash of samples of twelve afferent reprecentative grains. trable I on the following page gives the "expected range of anplysis", an the linits of these analyee vere oallod. Feble II sizows the perosutage oomposition of the "average anh". on the basis of a total of 100 \%. Thirty-six stendard nixtures vere prepared. of these there were six serios. In ench or which one of tre constituntes ocourrad in a different enount for eech of the gix nixtures in that sertes, perying by axbitrary aromits between the expected Iower rad upper limits of that parm izoular oxtie.

The romeinder of ean sarmie, on the portion excmatve of the dusired oxide, retalned the composition of tho average ash. In thlo rancer it wes postinge to waintain approxinately constant the effects of other elements present on the intensity of that waried, and at whe same time, Ir a gemies of six, to deternine the effect of variation in amounts of the firet the line intensitios 
TABLE I.

Expected Range of Grain Ash Analysis

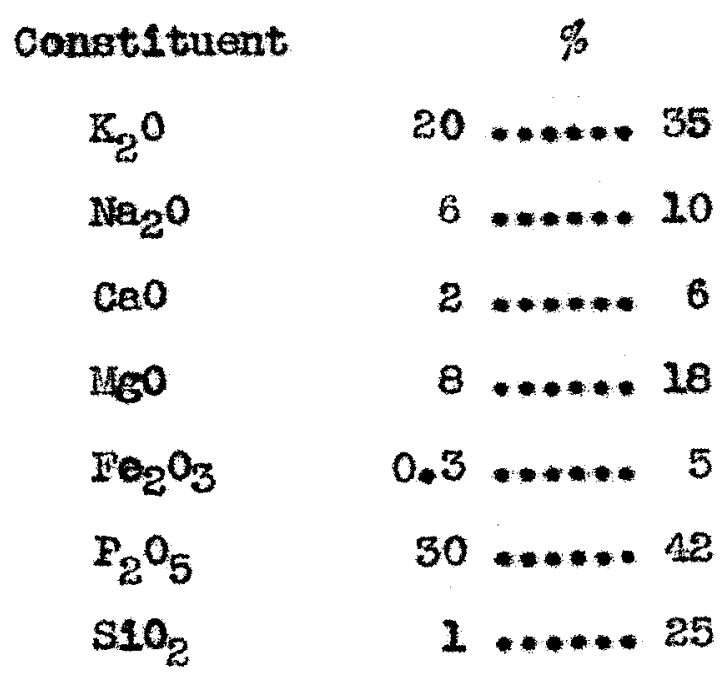

TABILE II.

Corposition of the "Average Ash"

$\begin{array}{lc}\text { congtituent } & \% \\ \mathrm{~K}_{2} \mathrm{O} & 26.40 \\ \mathrm{Na}_{2} \mathrm{O} & 7.69 \\ \mathrm{CaO} & 3.84 \\ \mathrm{HO} & 12.49 \\ \mathrm{Fe}_{2} \mathrm{O}_{3} & 2.54 \\ \mathrm{P}_{2} \mathrm{O}_{5} & 34.55 \\ \mathrm{SiO}_{2} & 12.49\end{array}$


of all the others. The percentage compositions of the varlous stondard mixtures are given in Table III.

A covenient method for calculating the percentage of any oxide in the atandard mixture is as follows: The desired percentage of the constituent being varied is subtracted from 100, and the percentage of that same constituent in the average ash is subtracted from 100. The remainder from the first operation divided by the remainder resulting in the second case gives a factor, $F$, by which the percentage of any oxide in the average ash oan be multiplied to give the percentage of that oxide in the corresponding standard mixture. The value of the factor, $F$, for each standard mixture appears at the bottorn of the data colurm for the compositions.

A study of the relative merits of tho internal standard method and the ratio quantitative system was undertaken. The relative amounts of the constituent axides was easily calculable from the data of the composition of the standard mixtures, so that a study of the second method was directly possible. For the first, molybdenum ves selected as the best available internal standard, and wes added to the samples to the extent of $2 \%$ with respect to the total oxides.

The standards were prepared volumetrieally. 
Solutions were prepared of emonium, potassiun, nagnestum, and iron sulfates, and of calcium nitrate and amoniwn phosphate in such concentrations that average rolumes of 20 to $30 \mathrm{ml}$. Of each solution $\mathrm{v}$ uld be necessary in the symthesis of each mixture. Silioa vas added gravi etrically in the form of silicle acid, the silica content of mich had been established by ignition. The ammoniun rolybdate solution was pipetted into exch mixture. A volure of 10 mil. was convenient, and the solution was prepared of such concentration that this volume would contain 0.2 gram of molybdenum. This calculation is shown in Table $\mathrm{V}$. Sufficient reagents vere usod that in ac case there would result 10 gn. of oxide. For an average sulfate ash, the total weicht would be twice that of the oxides alone, as shown in Table $V$. Therefore 20 gre is of armonium sulfate ws added to each mixture. This established then a constant ratio between tho veights or molybdenum, amonIura sulfate, and tho total oxides.

These mixtures were evaporated in beakers in a water bath. Contimual stirring and mixing insurod honogeneity, and residue on the walls of the beakers was washed down by a fine stream of vater containing a trace of sulfurlo acid. The ary residues were transforred to a clean mortar and ground $t$ fineness before being stored in clean 
labelled test tubes. A great deal of care was necessary to provent contamination of these samples, and all the equipment used was first cleaned with concentrated sulfuric acid and rinsed well with distilled water.

$A$ half bushel of corn was reduced to about 200 Grams of ash for the spectrographic and chemicel analyses. Wvaporating dishes were filled with the grain and $50 \mathrm{cc}$. each of ailute nitric and dilute sulfuric acias added. The mixture was then fired in the gas furnace, and ignited unt1l most of the carbon had been burned off. The residues were collected in a single dish, moistened with a slight anount of sulfuric acid, and reignited. All the final ashes vere carefully mixed and ground to homogenelty.

A representative sample of 10 grams was then removed and ground well with an egual weight of anmonium sulfate and sufficient anmoniun nolybdate to furnish 0.10 Gram of molybdenum.

Holes were drilled to a depth of about $3 / 16$ inch in the onds of the carbon rods to be used for lover electrodes with a $3 / 32$ inch drill, and the onds carefully ground conical in an ordinary pencil sherpener. To introduce and compress the specimens into these cavities the ends of the electrodes were pushed firmy into the rags of the samples. 
ualitative spectrograms were first taken to determine the lines of each elenent that could be easily identifled or were suitable for guantitative work. The spectrograph room had been equipped as a derk-roon, and the filn could be loaded directly without the necessity of removine the film holder. Inis was oovered vith a black cloth to protect the edges of the film from chance stray light. The shutter was closed and the metal slide removed. By means of the aligment pointer, the lower carbon containing the sample was clanped into the correct position. One operator then struck the arc and imediately videned the gap so that the white lines of the incandescent pole the dgreared beyond the ends of the slit. At the same time the second operator opened the shutter, and began tining a 45 second exposure. During this tine, the shunt plue was removed and the curront checked. All exposures vere conducted at 6 anperes. the the explration of tha exposure time the shutter was reloased and the rain switoh thrown off.

Whe filn holder ws then lowered tw notches for the quarter-inch slotted masl, the hot electrode dropped Into a container, and the new carbon with its sample as clamped into position. when this procedure was followed for the seven exposuros, a total time of less than ten minutes 

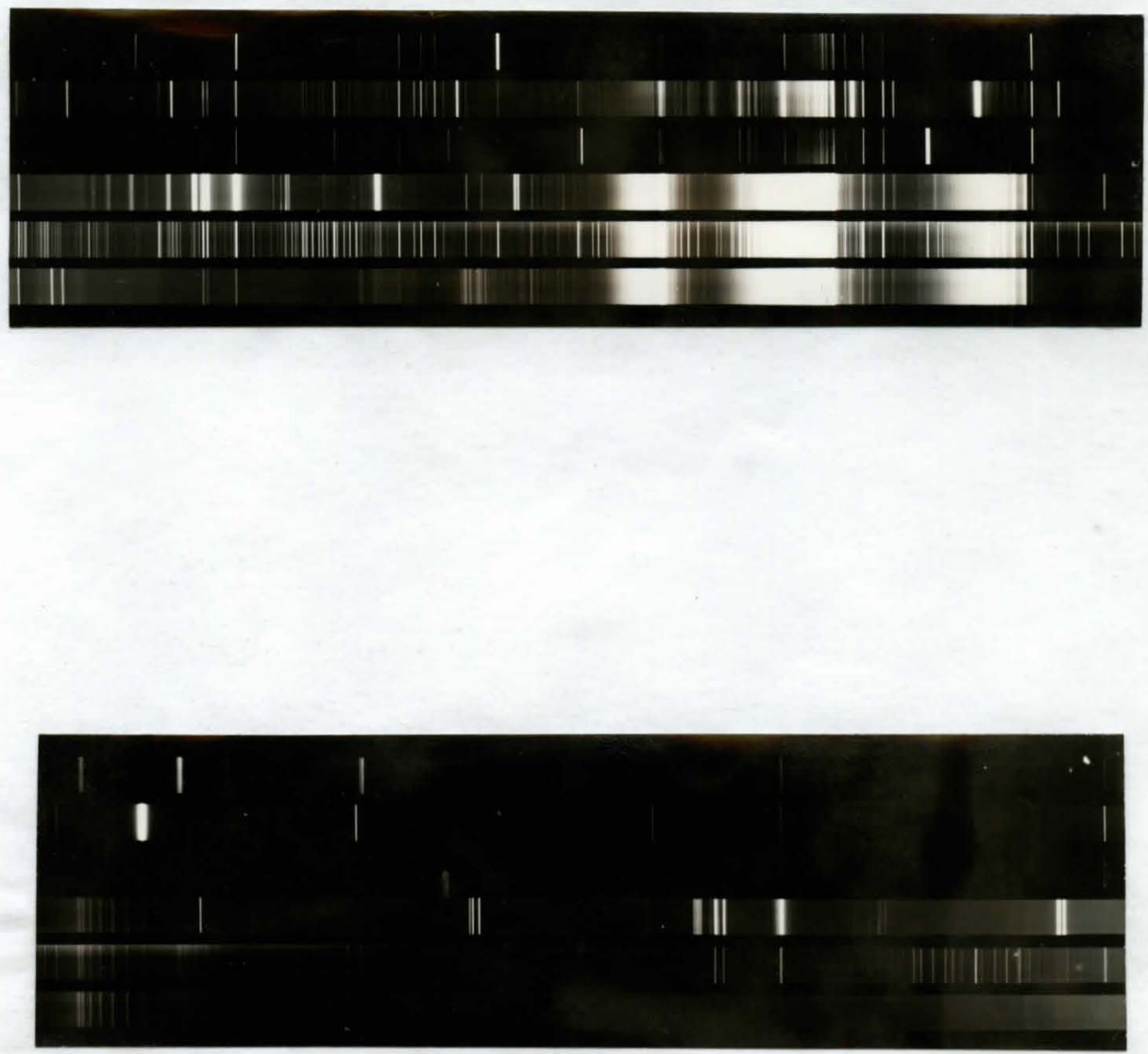

Figure 5. Qualitativve Spectrograms 
was required.

The film was removed in the darisened room and developed in Dit-50 developer at $15-16^{\circ} \mathrm{C}$. The optinum time for physical developmont in a tray was found to be throe minutes. This vas timed by stop-watch. The progress of development could be observed briefly from time to tine in the illumination from the dark green ratten Filter. After exactly three minutes the film was rinsed In a running strean of cold water for about a ninute, and then placed in a tray of saturated "hypo" fixing solution. Fifteen minutes was all wed for this process, and the negetive was then washed for twenty minutes before being hung to dry.

The order of appearance of the spectrograns on the film ves inverse to that of the exposures. Predoninant reference lines were established for the spectrum of each elenent, and by use of the measuring scale, the presence of lesser lines determined. Particulax attention was directed to those lines recomended in the literature for quantitative work $(3)(5)(6)(7)(10)(18)(19)$.

A similar program was followod in obtaining the quantitative spectrograns. First, however, the smaller nask was replaced by the $3 / 8$ inch slotted mask. This permitted only three exposures of each film, at pointer settings of 
3,7 , and 11 .

The electrodes vere handled carefully to avold contamination of the tips. Exposuros were exactly timed as before, and were begun imediately that the arc was struck, so that the spectrum of the more volatile constituents vould not be lost. the sector disk vas operated continuously.

Two horizontal chalk lines marked the ends of the exposed len th of tho slit. By proper setting of the upper electrode, the white pole bands of both carbons vere rad to colncide with these marks. This insured a constant arc gap width and at the same time avolded the entrance of light from the "pole spots" through the slit. The upper electrode was scrapol to a fresh surface followine each use.

The sane nethod of development was used. Tho doveloping solution held at $15-10^{\circ} \mathrm{C}$ to prevent brealing or slding of the gelatine film. burlng the development tine one operator relaaded the filn holder. The optinum times of develoment and exposure vere detemaned experinentally, and were timed by stop-watoh. whe effect of these variables is shown in Figure.

The dried film was narked at approximately 200 Angstrom unit intervals ( 0.5 inch each) vith reforence 
51
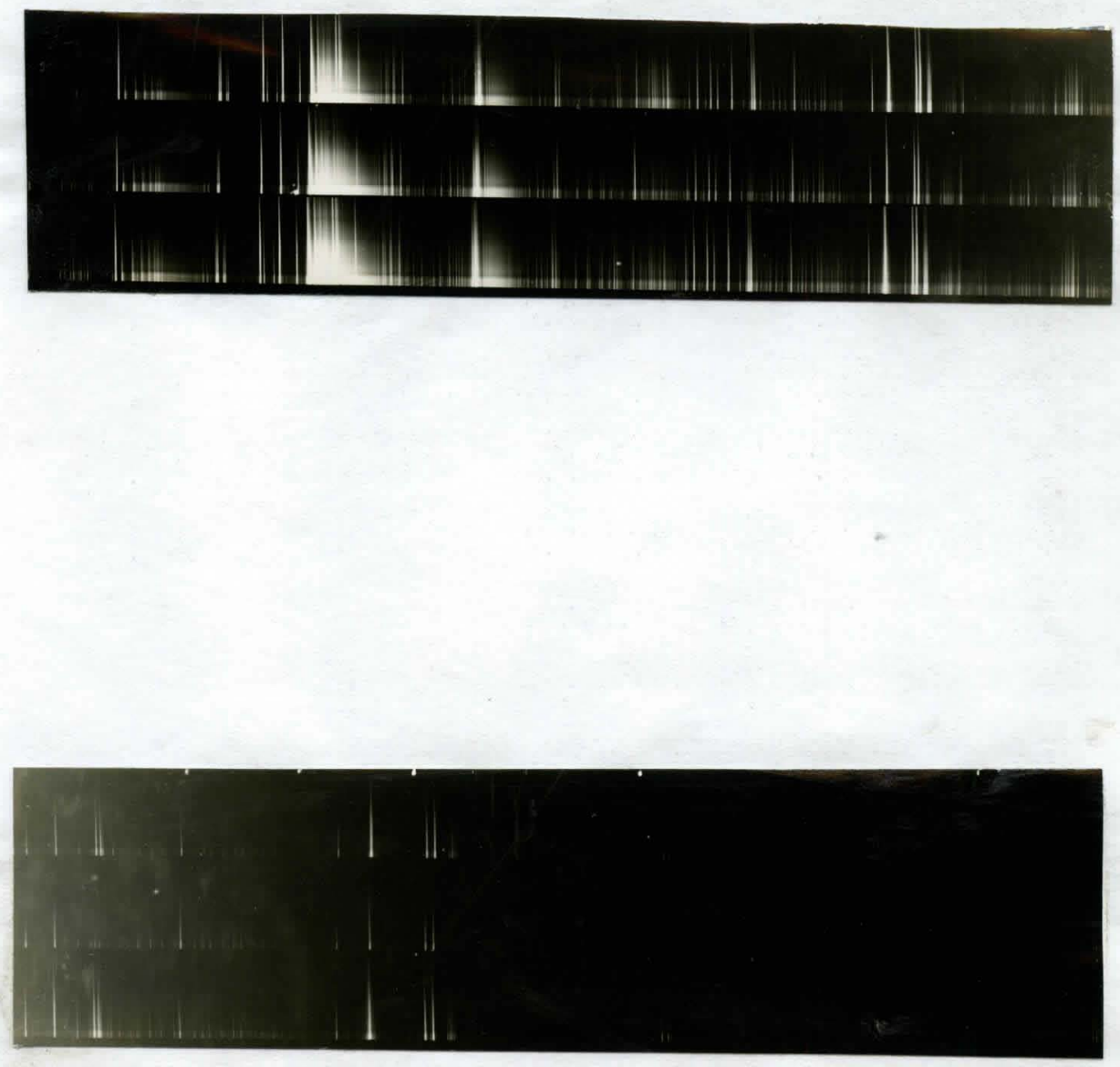

Figure 6. Representative quntitative Spectrogram 
to known lines. The film was then clamped between two plates of glass, and an enlarged image of it formed on the wall by means of a lantorn sllde projeotor. A magnification of $8 \times$ resulted, so that the ajepersion was $50 \mathrm{~A}^{\circ}$ per inch.

A wave-length scale of this nagnitude was prepared on a sheet of wite paper, coverine $200 \hat{i}^{\circ}(8$ incheg). When the end marks of this screen were made coincident vith the nunbered wave-length marks on the negatives, Ines of any were-ienth could easily be ldentified. The lengths of the lines desired wero measured from the base line in units 0.25 inch in length. These corresponded to lengths of $1 / 32$ inch on the original film.

The lines measured vere those of molybdenuri, calcium, macmesium, and those of the variant constituent. The differences in lengths of the lines of the latter and one of the first three were computed for all possible combinations.

For these date, curves were plotted to determine t e relationship between percentage amounts of each "varlant" constituent and the differences in lengths of the Ine pairs corresponding to these amounts. only those curves which followed approximately straight lines or appeared to be consistent functions vere reteinod. "Tho 
$\nabla:$ Iues of the coordinates of the eurves obteined are eiven in Table VII.

"Analytical curves" were drew shoving tho relation of the differences in lenths of line polrs, of which nolybdenum was a component, and the corresponding ercontages of the oxides of the other eloment. "Tatio guntitnt ve Curves" were obtained by plotting the differences in lengths of line pairs of the variant constituent and nagnesium or celcium against the ratios of the percenteges of the axides of the elements of those line pairs.

The ash semple was photogrephed in duplicate, and the len ths of all lines used in the other deterninations measured. Irom the so-celled operating ourves the analysis of the ash was established.

Three separate enalyses vere olloulated, based upon the molybdenum, colcium, and magnosium. The siog was cormuted by difference in each case. In the case of $\mathrm{Lg}$, the anount determined from the lo was assuned to be corroct. Ior the Ga, the amount was assumed to be thet roduired to give a total of constituents, exclusive of silica, oqual to tho averace of the totals in the other two ceses.

Juch experthental work was performed to de elop the acoessory ecuipment and to dotermine the operating characteristios of the spectrogra $h$ and $11 \mathrm{ma}$. 
DARA 
In the following table are given the compositions of the thirty-oix standard nixtures repared for obtaining the operatine curves for the anolysis of frein ash. Whe compostions are basel upon the " everage ash", the range of anyos of which has been shom in theble $\mathrm{I}$.

For ach series of six mixtures, we constituent oxido varies in cocentration between the lover and upper expecter linits of analysis. The range vas slightly extended for some oxides. The particular oxide under onsideration is designated as the "variant constituont". The romeinder of the sample hes the compostition of the average ash. By this means the effect of the other constituents on the line intensitios of the first is held approxinately constant. Also, the spoctra of the synthetic ash and those of the ectual ash will bo strictly comperable if the conditions of expltation are the sene.

If the percentage of the veried constituent is subtracted trom 100 in the etenderd nixture and in the average ash, the ratio of the remoinder in the rirst ase to thet resulting in the second gives a factor if. liultiplied by bis factor, the percentage of any oride in the average ash gives the anount of thet oxide in the stondard mixture. 


\section{PABLE III.}

Composition of Standard lilixtures

$\mathrm{K}_{2} \mathrm{O} \operatorname{Varied}$

\begin{tabular}{|c|c|c|c|c|c|c|}
\hline $\begin{array}{l}\text { Iurber of } \\
\text { Sample } \\
\%\end{array}$ & 1 & 8 & 3 & 4 & 5 & 6 \\
\hline $\mathrm{K}_{2} \mathrm{O}$ & 16.00 & 20.00 & 24.00 & 28.00 & 32.00 & 36.00 \\
\hline $\mathrm{Na}_{2} \mathrm{O}$ & 0.77 & 8.33 & 7.94 & 7.53 & 7.10 & 0.68 \\
\hline $\mathrm{CaO}$ & 4.38 & 4.17 & 3.97 & 3.76 & 3.54 & 3.34 \\
\hline$M_{g} \mathrm{O}$ & 14.27 & 13.60 & 12.90 & 12.23 & $\$ 1.55$ & 10.87 \\
\hline $\mathrm{Fe}_{2} \mathrm{O}_{3}$ & 2.90 & 2.76 & 2.62 & 2.49 & 2.35 & 2.21 \\
\hline $\mathrm{P}_{2} \mathrm{O}_{5}$ & 39.45 & 37.55 & 35.77 & 33.85 & 31.93 & 30.03 \\
\hline $\mathrm{SiO}_{2}$ & 14.27 & 13.00 & 12.90 & 12.23 & 11.54 & 10.87 \\
\hline Total & 100.00 & 100.03 & 100.03 & 100.09 & 100.01 & 100.00 \\
\hline$\approx \mathrm{K}_{2} \mathrm{O}$ & 16.00 & 20.00 & 24.00 & 28.00 & 32.00 & 36.00 \\
\hline Rem. & 84.00 & 80.00 & 76.00 & 7.00 & 68.00 & 64.00 \\
\hline II & 1.142 & 1.088 & 1.033 & 0.979 & 0.921 & 0.870 \\
\hline
\end{tabular}


Composition of Standard Mxtures

$$
\mathrm{Na}_{2} \text { O Varied }
$$

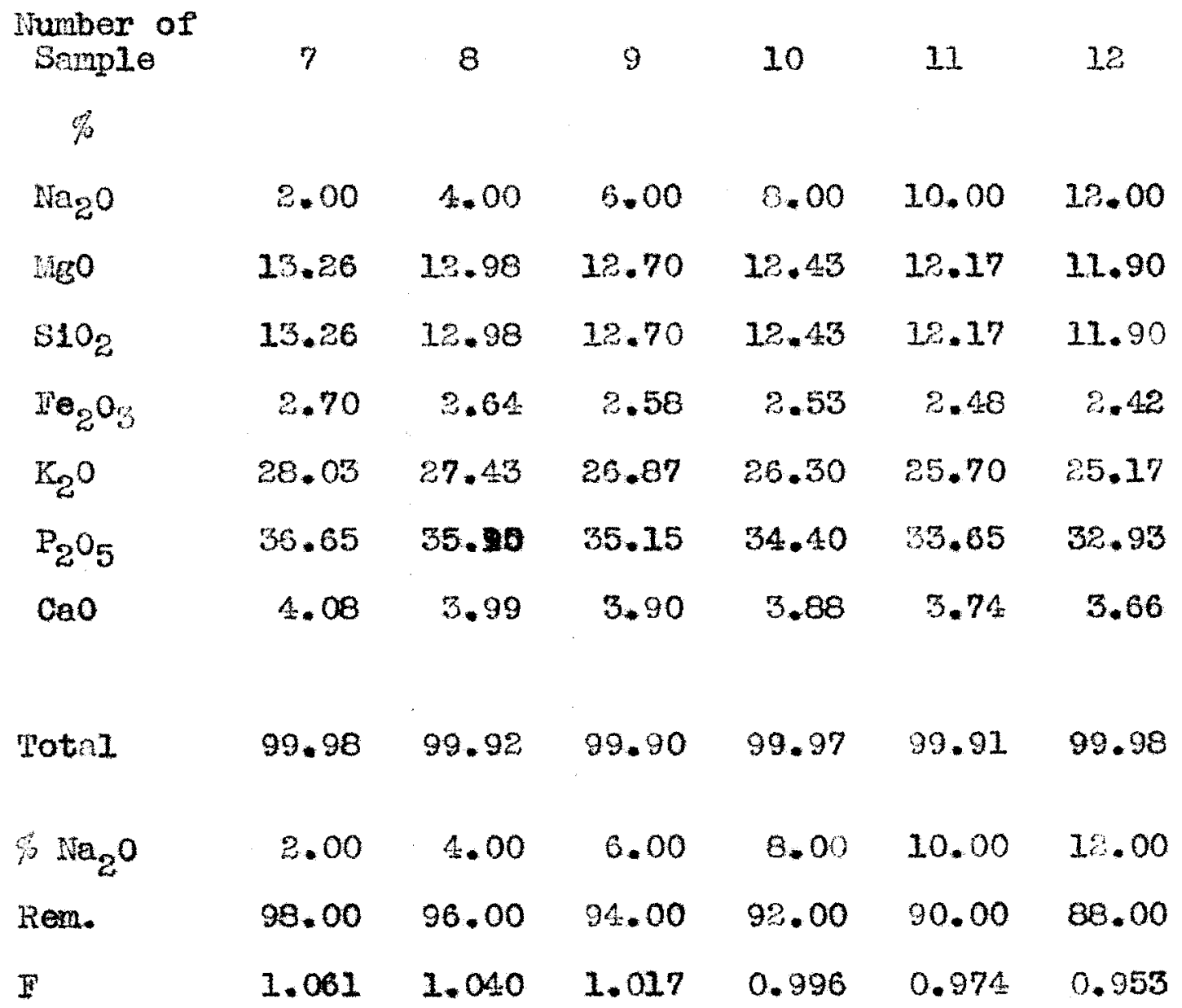


ABLW III.

$$
\begin{gathered}
\text { Compositior of standerd } 11 \text { xtures } \\
\text { Cao Varied }
\end{gathered}
$$

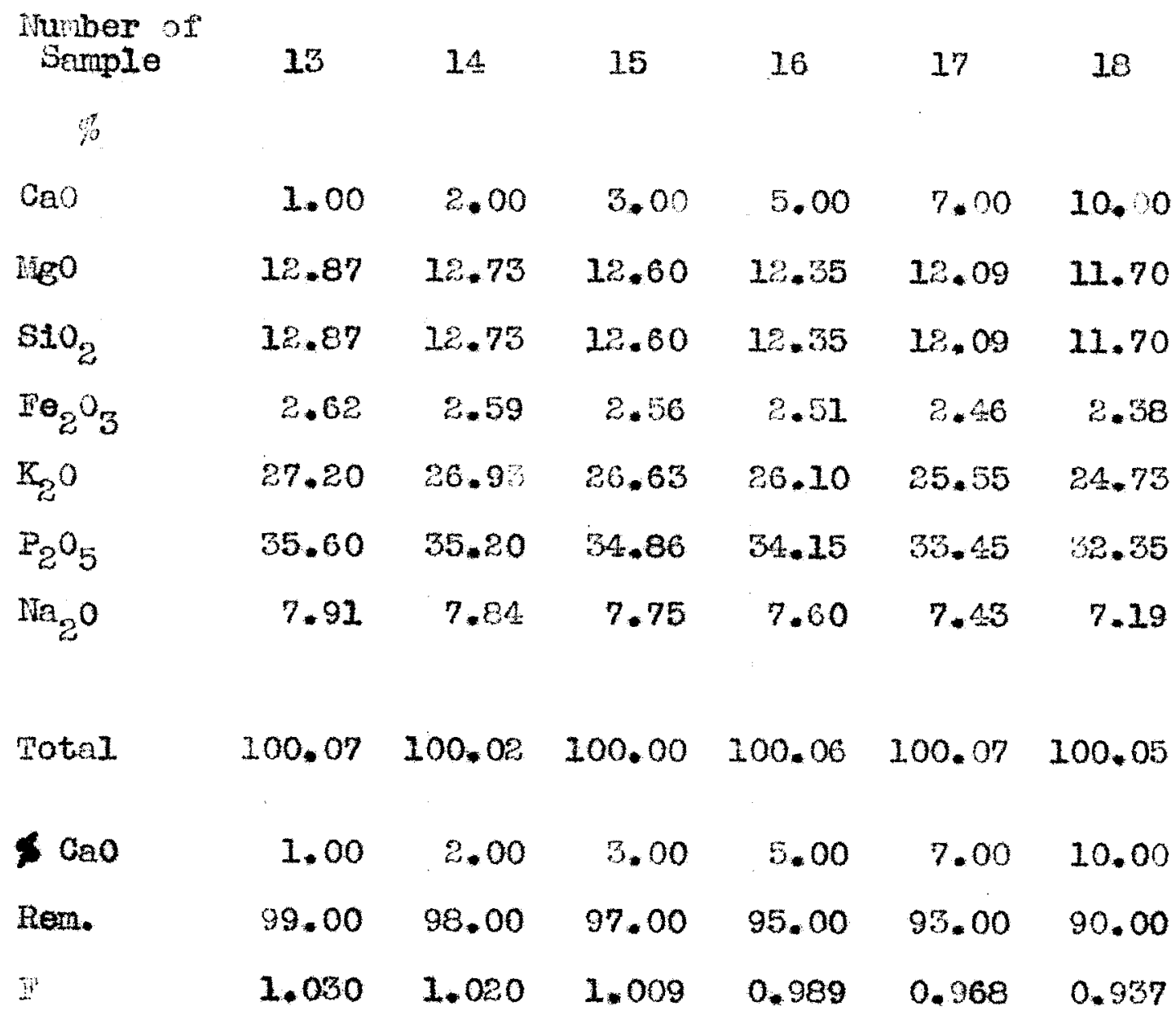


TABLE III.

Composition of stendard Hixtures

tigo Variod

\begin{tabular}{|c|c|c|c|c|c|c|}
\hline $\begin{array}{l}\text { INumber of } \\
\text { anplo } \\
\end{array}$ & 19 & 20 & 21 & 22 & 23 & 24 \\
\hline 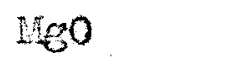 & 2.00 & 6.00 & 10.00 & 14.00 & 16.00 & 20.00 \\
\hline $\mathrm{SiO}_{2}$ & 13.99 & 13.41 & 12.85 & 12.28 & 12.00 & 21.42 \\
\hline $\mathrm{Fe}_{2} \mathrm{O}_{3}$ & 2.84 & 2.73 & 2.61 & 2.50 & 2.4 & 2.32 \\
\hline $\mathbb{R}_{2} 0$ & 29.55 & 28.35 & 27.16 & 25.95 & 25.35 & 24.15 \\
\hline $\mathrm{P}_{2} \mathrm{O}_{5}$ & 38.67 & 37.10 & 35.55 & 33.95 & 33.15 & 31.60 \\
\hline $\mathrm{CaO}$ & $\therefore 0$ & 4.12 & 3.95 & 3.78 & 3.68 & 3.51 \\
\hline $\mathrm{Na}_{2} \mathrm{O}$ & 8.60 & 8.25 & 7.90 & 7.55 & 7.37 & 7.03 \\
\hline rotal & 99.95 & 99.96 & 100.02 & 100.01 & 99.99 & 100.03 \\
\hline $8 \mathrm{ingo}$ & 2.00 & 6.00 & 10.00 & 14.00 & 16.00 & 20.00 \\
\hline Rem. & 38.00 & 94.00 & 20.00 & 86.00 & $8 . .00$ & 8.00 \\
\hline $\mathrm{E}$ & 1.120 & 1.073 & 1.088 & 0.9825 & 0.960 & 0.915 \\
\hline
\end{tabular}


ABLL III.

$$
\begin{aligned}
& \text { Composition of tandard llixtures } \\
& \qquad \mathrm{He}_{2} \mathrm{O}_{3} \text { Varied }
\end{aligned}
$$

\begin{tabular}{|c|c|c|c|c|c|c|}
\hline $\begin{array}{l}\text { Wumber of } \\
\text { Eample } \\
\%\end{array}$ & 25 & 26 & 27 & 28 & 29 & 30 \\
\hline $\mathrm{Pe}_{2} \mathrm{O}_{3}$ & 0.20 & 0.50 & 1.00 & 3.00 & 5.00 & 7.00 \\
\hline 510 & 12.80 & 12.75 & 12.68 & 12.42 & 12.18 & 11.91 \\
\hline LeO & 12.80 & 12.75 & 12.68 & 12.42 & 12.10 & 11.91 \\
\hline $\mathbb{K}_{2} 0$ & 27.05 & 26.95 & 26.80 & 26.27 & 25.73 & 25.20 \\
\hline $\mathrm{P}_{2} \mathrm{O}_{5}$ & 35.40 & 35.25 & 35.07 & 34.40 & 33.66 & 32.95 \\
\hline $\mathrm{CaO}$ & .93 & 3.92 & 3.90 & .82 & 8.74 & 3.66 \\
\hline $\mathrm{Na}_{2} \mathrm{O}$ & 7.87 & 7.83 & 7.80 & 7.65 & 7.59 & 7.33 \\
\hline Totel & 100.05 & 99.95 & 99.93 & 99.98 & 99.90 & 99.96 \\
\hline $83 e_{2} 0_{3}$ & 0.20 & 0.50 & 1.00 & 3.00 & 5.00 & 7.00 \\
\hline Fom. & 99.80 & 99.50 & 99.00 & 97.00 & 95.00 & 93.00 \\
\hline $\mathrm{F}$ & 1.024 & 1.020 & 1.015 & D. 995 & 0.975 & 0.953 \\
\hline
\end{tabular}


WABLE III.

Conposition of Standard Mixtures

$\mathrm{P}_{2} \mathrm{O}_{5}$ Varjed

\begin{tabular}{|c|c|c|c|c|c|c|}
\hline $\begin{array}{l}\text { Wumber of } \\
\text { Somple } \\
\%\end{array}$ & 31 & 32 & 35 & $3 A$ & 35 & 30 \\
\hline $\mathrm{P}_{8} \mathrm{O}_{5}$ & 20.00 & 24.00 & 28.00 & 32.00 & 36.00 & 40.00 \\
\hline $\mathrm{SLO}_{\mathrm{z}}$ & 15.27 & 14.50 & 13.73 & 12.97 & 12.20 & 11.45 \\
\hline 100 & 15.27 & 11.50 & 13.73 & 18.97 & 12.20 & 32.45 \\
\hline $\mathrm{Fe}_{2} \mathrm{O}_{3}$ & 3.10 & 2.94 & 2.0 & 2.04 & 2.48 & 2.33 \\
\hline$K_{2} 0$ & 32.25 & 30.60 & 29.03 & 27.43 & 25.80 & 24.20 \\
\hline $\mathrm{CaO}$ & 4.69 & 4.46 & 4.23 & 3.99 & 8.76 & 3.52 \\
\hline $\mathrm{Ne}_{2} \mathrm{O}$ & 0.38 & 0.92 & $8 . \div 5$ & 7.98 & 7.52 & 7.04 \\
\hline
\end{tabular}

Totel

$\begin{array}{llllll}99.96 & 99.92 & 99.97 & 09.98 & 99.00 & 99.39\end{array}$

$\begin{array}{lllllll}\% \mathrm{P}_{2} \mathrm{O}_{5} & 20.00 & 24.00 & 28.00 & 32.00 & 30.00 & 40.00\end{array}$

Ren. $\quad 80.00 \quad 76.00 \quad 72.00 \quad 68.00 \quad 64.00 \quad 60.00$

F

$\begin{array}{llllll}1.221 & 1.160 & 1.100 & 1.038 & 0.976 & 0.917\end{array}$ 
In the preparation of the standard mixtures, it vas desirable to use volunes of reagent solutions of the order of 20 to $30 \mathrm{ml}$. Also, for the purpose of convenience in calculatio., it was advantageous that the concentration of each solution be such that each ml. represented some definite fraction of a gran of the corresponding oxtale. In the table on the following page are shown the factors used to celculate th weight of reagents used in preparing the solutions, and those for conversion of percent oxides in the tables of comosition of standard mixtures to $\mathrm{ml}$. of solutions.

The equivalent weights of oxide and reagent signify the weight of substance in grans equivalent to a gram atom of the element under consideration. Factor $X$ is the ratio of the equiralent weight of the reagent to that of the corresponding oxide. $Y$ is the reciprocal of the number of inl. containing 0.1 gran of oxide. The number of grans of reagent per liter is then determined by multiplying $x$ by $100 \mathrm{Y}$. For $\mathrm{ml}$. of solution to be used in preperation of the standard mixtures, the percentage amounts are rultiplied by the factor I/ $Y$.

The total weight of oxides resulting in each mixture is 10.00 grams. 
MABLE IY.

Gravimetric and Volunetric Factors

\begin{tabular}{|c|c|c|c|}
\hline oxide & $\begin{array}{c}\text { Butvalent } \\
\text { Weight }\end{array}$ & Reagent & $\begin{array}{l}\text { Hquivelent } \\
\text { Welght }\end{array}$ \\
\hline $\mathrm{r}_{2} \mathrm{O}$ & 48.1 & $\mathrm{~K}_{2} \mathrm{SO}_{4}$ & 87.13 \\
\hline $\mathrm{Na}_{2} \mathrm{O}$ & 35.0 & $\mathrm{Na}_{2} \mathrm{SO}_{4}$ & 71.02 \\
\hline $\mathrm{CaO}$ & 56.07 & $\mathrm{Ca}\left(\mathrm{NO}_{3}\right)_{2}$ & 164.10 \\
\hline $\mathrm{MgO}$ & 40.32 & $\mathrm{MgSO}_{4}$ & 120.38 \\
\hline $\mathrm{Fe}_{2} \mathrm{O}_{3}$ & 79.84 & $\mathrm{Fe}\left(\mathrm{HH}_{4}\right)_{2}\left(\mathrm{SO}_{4}\right)_{2} \cdot 6 \mathrm{H}_{2} \mathrm{O}$ & 392.54 \\
\hline $\mathrm{P}_{2} \mathrm{O}_{5}$ & 71.02 & $\left(\mathrm{NH}_{4}\right)_{2} \mathrm{HPO}_{4}$ & 132.11 \\
\hline $310_{2}$ & 60.06 & $\mathrm{H}_{2} \mathrm{Si}_{3} \mathrm{O}_{7}$ & $60.06 / 0.911$ \\
\hline
\end{tabular}

Reagent

Pactor $X \quad$ Factor $Y$ Grans/Liter

$\mathrm{K}_{2} \mathrm{SO}_{4}$

1.85

$1 / 2$

92.50

$\mathrm{Na}_{2} \mathrm{SO}_{4}$

2.29

$1 / 3$

76.33

$\mathrm{Ca}\left(\mathrm{NO}_{3}\right)_{2}$

2.93

$1 / 6$

48.80

$\mathrm{ILSO}_{4}$

8.985

$1 / 2$

169.25

$\mathrm{Fe}\left(\mathrm{NH}_{4}\right)_{2}\left(\mathrm{SO}_{4}\right)_{2} \cdot 6 \mathrm{H}_{2} \mathrm{O}$

4.92

$1 / 10$

49.20

$\left(\mathrm{IH}_{4}\right)_{2} \mathrm{HPO}_{4}$

1.86

$1 / 1$

186.00

$\mathrm{H}_{2} \mathrm{SI}_{3} \mathrm{O}$

1.10

$1 / 1$ 
TABLE V.

Amounts of Internal Standard and Diluent Substance flded to standard Mixtures

$1000 \mathrm{ml} . \times 10 \mathrm{gm}$. oxide $\times 0.02 \mathrm{mz}$. ino/ gm. oxide $10 \mathrm{mI}$.

$$
=20 \mathrm{gm} \text {. Wo / Litor }
$$

\begin{tabular}{|c|c|c|c|}
\hline Oxide & $\begin{array}{l}\text { Grams oxide in } \\
10 \text { Grams of } \\
\text { Average Ash }\end{array}$ & $X$ & $\begin{array}{l}\text { Grans of } \\
\text { Reacent }\end{array}$ \\
\hline $\mathrm{K}_{2} \mathrm{O}$ & 2.60 & 1.85 & 4.8 \\
\hline $\operatorname{Ma}_{2} \mathrm{O}$ & 0.77 & 2.29 & 1.76 \\
\hline $\mathrm{CaO}$ & 0.384 & 2.93 & 1.11 \\
\hline $\mathrm{Mg} 0$ & 1.25 & 2.99 & 3.74 \\
\hline $\mathrm{Fe}_{8} \mathrm{O}_{3}$ & 0.25 & 4.92 & 1.23 \\
\hline $\mathrm{P}_{5} \mathrm{O}_{5}$ & 3.46 & 1.86 & 0.43 \\
\hline $\mathrm{SIO}_{2}$ & 1.25 & 1.10 & 1.37 \\
\hline Total & 10.00 & & 20.44 \\
\hline
\end{tabular}


In the following Table are listed spectrol lines of the elenents studied in this research, which vere recomnended in the literature. The bibliography numbers of the reforence articles fron hich each wes taken are eiven. In addtion to those listed it was necessary to solect several lines from the cuelitative spectrograns. In Table VIII, the coordinates of the operatine curves are tabulated. The values listed are those of $\Delta I$, in unlts of $1 / 4$ inch on the enlarged image, or $1 / 30$ inch on the negatives. These values were obtained as the differences in lengths of members of line pelrs, these being designated in the table. The column fall under percentages of the constituent for analytical curves, and under ratios of the varied constituent and igo or CaO for the retio quantitative curves.

Irom that table have beon excluded in a fow coses points wich ald not agree with the general trend of the varlous curves. However, no point was rejocted unless there vere at least four others which did fall into an approxinatoly straight line. In that case, the point not in agreonent was as uned to be in error. Not all poss blo conbinstions of lino peirs resulted in snooth curves, and only those givine straight inos or consistent functions vore retained. 
TABLE TI.

Spectrum Lines Recomended in the Iiterature for uantitative inalysis

\begin{tabular}{llllll}
\multicolumn{3}{c}{35} & \multicolumn{2}{c}{ No } \\
7665 & $(19)$ & 3302 & $(5)(6)$ & 3816 & $(7)$ \\
3447 & $(10)$ & 5890 & $(18)(29)$ & 3123 & $(19)$ \\
4044 & $(5)$ & 5890 & $(18)$ & 3158 & $(7)$ \\
4046 & $(6)$ & & & 3903 & $(7)$
\end{tabular}

\begin{tabular}{llllll}
\multicolumn{2}{c}{ Ca } & \multicolumn{2}{c}{ Fe } & \multicolumn{2}{c}{ is } \\
$3159(10)$ & 2483 & $(19)$ & 2777 & $(10)$ \\
3179 & $(10)$ & 2599 & $(10)$ & 2780 & $(10)$ \\
3247 & $(5)$ & 2698 & $(10)$ & $2795(7)$ \\
3934 & $(18)$ & 2719 & $(3)$ & $2852(3)(5)$ \\
$3969(18)$ & $3020(3)(7)$ & $3074(3)(10)$ \\
$4226(5)(6)$ & & & 3832 & $(3)$ \\
& $(7)(19)$ & & & &
\end{tabular}

P

2536 (10) 
Coordinates of operatine curves

\begin{tabular}{|c|c|c|c|c|c|}
\hline oxide & & cont 0 & ide in & stondo & \\
\hline ine Pair & & $\operatorname{Valu}$ & $s$ of & & \\
\hline $\mathrm{K}_{2} \mathrm{O}$ & 16 & & 20 & & 36 \\
\hline aa $\angle 3447$ - 302660 & 5.0 & & 0.5 & & 4.0 \\
\hline$b b+3447-1108810$ & 1.0 & & -2.0 & & 2.0 \\
\hline cc 1 r $3447-1103122$ & 2.5 & & 0.0 & & 4.0 \\
\hline $\operatorname{Na}_{3} 0$ & 2 & 6 & 8 & 10 & 12 \\
\hline a ila 5281 - No 2816 & 4.0 & $亡$ & 2.5 & 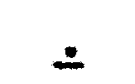 & 1.0 \\
\hline $\mathrm{bb}$ iva 3381 - 110 3158 & 0.5 & - & 3.5 & 5.0 & 2.0 \\
\hline $\mathrm{co} \mathrm{Na} 5209-1105816$ & -4.5 & -3.0 & -2.0 & - & - \\
\hline da He 5890 - Ho 2660 & -4.5 & -3.0 & - & - & 5.5 \\
\hline ee ila 5890 - No 2816 & -7.0 & -4.0 & - & - & 1.5 \\
\hline ff ha 5890 - Ino 3122 & -5.0 & -3.0 & - & - & 1.5 \\
\hline GE Na 5890 - Lio 3158 & -4.5 & -3.0 & - & - & 2.5 \\
\hline hh Na 5896 - Mo 2816 & 5.0 & 3.0 & 3.0 & - & -1.0 \\
\hline Cro & 1 & 2 & 3 & 7 & 10 \\
\hline a $\mathrm{Ca} 3179$ - Lo 2816 & -3.5 & 7.5 & 2.5 & 4.0 & - \\
\hline $\mathrm{bb} \mathrm{Ca} 3179-1103122$ & -1.5 & 2.0 & 2.5 & 6.5 & - \\
\hline $\mathrm{co} \mathrm{Ce} 4226-1102660$ & -2.0 & 2.5 & - & 3.5 & 4.25 \\
\hline
\end{tabular}


DAEIE VII.

Coordinates of Operating Gurves

oxide

Ine Pairs

$\mathrm{CaO}$

da $\mathrm{Ce} 4226$ - Mo 2816

ee Ca 4226 - Ho 3122

ff Ca $4226-$ Io 3158

180

aa the 2777 - Wo 3122

bb $1183030-$ Lo 2660

co $\operatorname{lgg} 3030$ - 1102816

dd $14 \mathrm{c} 3030-1503122$

ee $\operatorname{lig} 3077$ - Mo 2660

ff itg 3077 - 110 312a

$\mathrm{Ze}_{2} \mathrm{O}_{3}$

ae Ie 2483 - No 2660

bb Fe 2483 - 1 Ho 2816

ce Te $2599-1$ Ho 2816

da le 2698 - No 2660

ee $\mathrm{Fe} 2698$ - No 2816
Pexcent oxide in Standard

Value of $\Delta I$

1

3

3

7

10

$\begin{array}{ccccc}-2.5 & 1.0 & 0.0 & - & - \\ -0.5 & 1.5 & - & 4.0 & 4.25 \\ 43.0 & - & 0.5 & - & -3.75\end{array}$

$\begin{array}{lllll}2 & 6 & 14 & 16 & 20\end{array}$

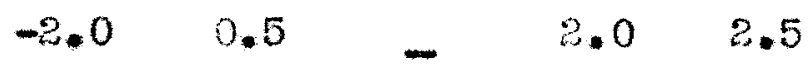

$\begin{array}{llll}7.25 & \mathbf{1 . 5} & 0.0\end{array}$

$-\quad-\quad-5.25 \quad-3.0 \quad 0.0$

$\begin{array}{lllll}-1.25- & -0.25 & 1.0 & 4.5\end{array}$

$7.5 \quad 5.25-2.25=$

$\begin{array}{lllll}-0.5 & -0.5-3.25 & -\quad 6.5\end{array}$

$\begin{array}{lll}0.2 & 0.5 & 1.0\end{array}$

$\begin{array}{lll}0.5 & 3.0 & 1.0\end{array}$

$\begin{array}{lll}-2.0 & 0.0 & -1.0\end{array}$

$\begin{array}{lll}-1.5 & 1.0 & 0.0\end{array}$

$\begin{array}{lll}-1.5 & -2.0 & -1.0\end{array}$

$\begin{array}{lll}-0.0 & -5.0 & -3.0\end{array}$ 
TABLE VII.

Coordinates of Operating Curves

Oxtde

Line Pairs

$\mathrm{Pe}_{2} \mathrm{O}_{3}$

ff tie 3020 - No 2660

gE Fe 3020 - ho 2810

$$
\mathrm{P}_{2} \mathrm{O}_{5}
$$

aa P 2534 - Mo 2816

bb P 2553 - Io 2816

cc P 2644 - 1102816

dd P 2725 - 乩O 2816

ee P 2644 - L 2660

ff P 2725 - ITo 2660

68 P 2884 - ho 2660

hh P 2896 - 10 2660

ii P 2644 - Mo 3122

jJ $P 2725$ - 103122

kk. 2 2884 - No 3122

11 P 3425 - 103122
Percent oride in standard

Talue of $\triangle I$

$\begin{array}{rrr}0.2 & 0.5 & 1.0 \\ 7.0 & 10.5 & 7.0 \\ 4.5 & 7.5 & 5.0\end{array}$

$20 \quad 24 \quad 28 \quad 38 \quad 36$

$\begin{array}{lllll}-0.5 & -0.25 & 1.0 & 4.0\end{array}$

$\begin{array}{llll}- & -2.25 & 0.5 & 2.5\end{array}$

$\begin{array}{llll}-4.5 & -3.75 & 3.0 & 0.5\end{array}$

- -2.25 3.56 .5 -

$\begin{array}{lll}-1.5 & -0.5-1.0 \quad 5.0\end{array}$

$-1.0 \quad 5.5 \quad 7.0$ -

- $1.56 .0 \quad 7.0$ -

$3.0 \quad 1.0 \quad 0.5 \quad-\quad-1.0$

$\begin{array}{rllll}-5 & - & -1.5 & 0.0 & 2.0\end{array}$

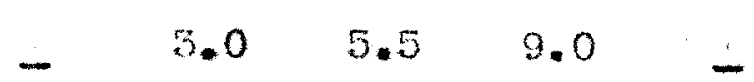

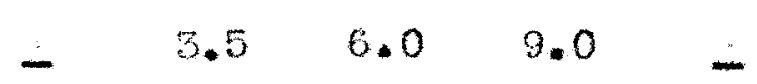

$3.55 .0-8.0=$ 
TAELE VTI.

\section{Coordinates of Operating Curres}

\begin{tabular}{|c|c|c|c|c|}
\hline oxide Ratio & & uentitat & ve Ratio & \\
\hline Lino Pairs & & Volue & $f \Delta I$ & \\
\hline $\mathrm{K}_{2} \mathrm{O} / \mathrm{CaO}$ & 3.66 & & 80 & 10.76 \\
\hline ad $3447-\mathrm{Ca} 3179$ & 3.5 & -0 & & -2.25 \\
\hline $\mathrm{bb}: 3447-\mathrm{Ca} 3934$ & 0.5 & -0 & & -1.0 \\
\hline ce $\quad 3447-C a 4578$ & 1.0 & & & 2.0 \\
\hline $\mathrm{I}_{2} \mathrm{O} / \mathrm{MEO}$ & 1.12 & & 47 & 3.31 \\
\hline a $\mathrm{II} 3446$ - ME 3030 & 4.5 & -3 & & 0.0 \\
\hline $\mathrm{Na}_{2} \mathrm{O} / \mathrm{CaO}$ & 0.49 & 1.54 & 2.06 & 3.28 \\
\hline aa $\mathrm{Na} 3781$ - Ca 3179 & 7.0 & - & 2.5 & -8.0 \\
\hline $\mathrm{bb} \mathrm{Na} 5209$ - Ca 3215 & -4.0 & -6.0 & -7.0 & - \\
\hline ce ive $5896-C_{0} 3179$ & 6.0 & 2.5 & - & -3.0 \\
\hline de $1 \mathrm{He} 5896-\mathrm{Ca} 3215$ & 3.5 & 0.0 & -5.0 & - \\
\hline $\mathrm{Me}_{2} \mathrm{O} / \mathrm{MgO}$ & 0.151 & 0.473 & 0.657 & 1.01 \\
\hline de Ne $5209-M_{B} 9777$ & -5.0 & -3.5 & -1.0 & - \\
\hline bb $165209-188077$ & -8.0 & -6.25 & -5.5 & - \\
\hline co ina $5890-1$ - 2777 & -7.5 & -4.5 & - & -2.5 \\
\hline da ina $5890-4 b 5077$ & -10.5 & -7.25 & - & -0.5 \\
\hline ee Na $5896-1 \mathrm{ig} 3077$ & 0.5 & -0.25 & -0.5 & -3.0 \\
\hline
\end{tabular}


TALU VII.

Coordinates of Oporating curves

Oxide Ratio

tine Pairs ouentitative Rotio

Value of $\Delta I$

\begin{tabular}{|c|c|c|c|c|c|c|}
\hline & $\mathrm{CaO} / \mathrm{ILgO}$ & 0.0777 & 0.157 & 0.238 & 0.58 & 0.855 \\
\hline $\mathrm{ae} \mathrm{Ca}$ & $317-463030$ & -3.5 & 0.0 & 1.5 & 3.0 & - \\
\hline $\mathrm{bb} \mathrm{Ca}$ & $3215-156077$ & - & -1.5 & -0.5 & - & 1.0 \\
\hline $\mathrm{COCa}$ & $3934-182777$ & - & 3.0 & 1.5 & - & -3.0 \\
\hline $\mathrm{da} \mathrm{Ca}$ & $3934-1485077$ & - & - & 1.0 & -0.5 & -3.0 \\
\hline ee $\mathrm{Ca}$ & $4226-1483030$ & -2.5 & -0.5 & 5.0 & - & - \\
\hline $\mathrm{fPCa}$ & $4326-1205077$ & - & -2.5 & - & -1.5 & 0.0 \\
\hline & $190 / \mathrm{CaO}$ & 0.465 & 1.46 & 3.70 & 4.35 & 5.70 \\
\hline aa $\mathrm{Mg}$ & $2777-\mathrm{Ca} 3215$ & - & 5.0 & 2.0 & 0.0 & -4.5 \\
\hline bb ing & $2777-\mathrm{Ce} 3247$ & -5.0 & -4.0 & -1.0 & -2.0 & -5.5 \\
\hline $\cos \bar{L}$ & $3077-\mathrm{Ca} 3215$ & - & 4.0 & 2.0 & 1.25 & -0.5 \\
\hline da leg & $3077-\mathrm{Ca} 4578$ & - & -4.0 & - & 0.35 & 2.5 \\
\hline & $e_{2} o_{3} / n_{60}$ & 0.0156 & & 0.0398 & & 0.079 \\
\hline ae Fo & $2483-M_{B} 3030$ & -2.0 & & -3.0 & & -4.0 \\
\hline $\mathrm{bb} \mathrm{Fe}$ & $3020-485077$ & 3.75 & & 3.0 & & -1.0 \\
\hline
\end{tabular}


TABLE VII.

Coordinates of Operating Curves

uxide Ratio

Iine Pairs

$\mathrm{He}_{2} / \mathrm{daO}$

a Te 2403 - Ca 3179

b) we $9403-\mathrm{Ca} 3247$

co $10.883-\mathrm{Ca} 3934$

da $202483-0 n 4256$

e€ Ie 2599 - Ce 5179

fr Le $2599-\mathrm{Ca}, 247$

G8 2 e 2599 - Ce 5934

hh Fe 2698 - Co 3179

i1 Te $2098-$ Ce 5215

jง $102698-003247$

lak $\mathrm{He} 2698-\mathrm{Ca} 3934$

11 Ve 2688 - Ca 4226

nin ie $5020-$ Ca 3215

nn 203020 - Ca 3247

oO IO 5020 - Ca 3934

pp Le 3020 - Co 4260
Quentitative Ratio

Value of $\Delta I$

$$
0.051
$$

0.128

0.556

$-9.0$

$-7.0$

$-3.0$

$-5.0$

$-3.5$

$-40$

$-2.5$

$-1.0$

$-3.0$

0.5

6.0

$-1.5$

$-9.0$

$-6.0$

$-5.0$

$-1.5$

$-3.0$

0.5

$-2.0$

$-2.5$

$-12.0$

$-8.0$

$-11.0$

$-5.5$

$-3.0$

$-4.5$

$-0.5$

$-5.5$

$-7.0$

$-4.5$

$-6.0$

$-5.0$

$-1.5$

$-1.0$

$-0.5$

2.0

7.0

4.0

0.5

A. 0

2.0

4. 0

7.0

3.0

7.0

11.5

7.5 
Coordinates of operating curves

\begin{tabular}{|c|c|c|c|c|c|c|c|}
\hline & oxido & natio & & guanti & gative & atio & \\
\hline & Line & Deirs & & $\mathrm{Tal}$ & de of $\Delta$ & & \\
\hline & $P_{2} O_{5}$ & $/$ DaO & 0.62 & 0.785 & 0.965 & 1.17 & 1.595 \\
\hline aa $\mathrm{P}$ & 2534 & - Ca 8934 & -0.5 & 0.0 & 1.0 & 3.5 & - \\
\hline $\mathrm{bb} P$ & 5534 & - Ca 4578 & 3.0 & 4.0 & - & 6.5 & - \\
\hline co P & 2553 & - Ca 3170 & - & -6.0 & -1.0 & 2.0 & 4.0 \\
\hline dd $p$ & 2553 & $-\operatorname{Ca} 3934$ & - & -2.0 & -0.5 & 2.0 & 5.5 \\
\hline ee ? & 3664 & - Ca 3179 & - & -7.5 & -4.5 & -0.0 & 1.0 \\
\hline ff $P$ & 5725 & - Ca 3170 & - & -6.0 & 8.5 & 6.0 & - \\
\hline SE $\mathrm{P}$ & 2884 & - Ca 3179 & - & -5.5 & 3.5 & 0.0 & - \\
\hline his $P$ & 2884 & - Ca 3934 & - & -1.5 & 4.0 & 0.0 & - \\
\hline ii $p$ & 2884 & - Ca 4226 & - & 0.5 & 3.5 & $\therefore .0$ & - \\
\hline$j j 2$ & 3245 & - Ca 3179 & - & -4.0 & 0.0 & 5.0 & - \\
\hline $1 \mathrm{kK} \times 2$ & 2896 & - Ca 32.47 & -3.0 & -3.0 & - & -5.0 & -6.0 \\
\hline & $P_{2} 0_{5}$ & $/$ 絈o & 1.31 & 1.66 & 2.04 & 2.47 & 2.95 \\
\hline a $\mathrm{P}$ & 2534 & $-4 g$ & 1.5 & - & 0.0 & - & -8.0 \\
\hline $\mathrm{bb} P$ & 2896 & $-M_{C} 2777$ & 1.5 & 1.0 & - & -2.0 & -3.0 \\
\hline
\end{tabular}


ABLE VIII.

Regults of Spectrographic Malysis of Corn $\mathrm{Ash}$

\begin{tabular}{|c|c|c|c|c|c|}
\hline $\begin{array}{l}\text { oxide or } \\
\text { oxide Ratio }\end{array}$ & Curve & $\Delta L$ & $\begin{array}{c}\not 1 \\
\text { oxide }\end{array}$ & $\begin{array}{l}\text { Oxide } \\
\text { Ratio }\end{array}$ & Average \\
\hline \multirow[t]{3}{*}{$K_{2} 0$} & $a b$ & 7.5 & 15.0 & & \\
\hline & $\mathrm{bb}$ & 4.5 & 15.0 & & \\
\hline & co & 6.0 & 15.0 & & $15.0 \%$ \\
\hline \multirow[t]{2}{*}{$\mathrm{K}_{2} \mathrm{O} / \mathrm{CaO}$} & $a A$ & 7.0 & & 3.4 & \\
\hline & $\mathrm{bb}$ & $A .0$ & & 3.3 & 3.35 \\
\hline $\mathrm{K}_{2} \mathrm{O} / \mathrm{K} \mathrm{K}_{\mathrm{g}} \mathrm{O}$ & $\mathrm{aa}$ & $\therefore .5$ & & 1.1 & 1.1 \\
\hline \multirow[t]{3}{*}{$\operatorname{lig}_{2} 0$} & $\mathrm{dd}$ & 0.0 & 9.7 & & \\
\hline & ee & -3.0 & 7.3 & & \\
\hline & ff & -1.5 & 8.3 & & $8.22 \%$ \\
\hline \multirow[t]{2}{*}{$\mathrm{Na}_{2} \mathrm{O} / \mathrm{CaO}$} & $c c$ & -2.0 & & 3.0 & \\
\hline & $\mathrm{da}$ & -4.0 & & 2.6 & 2.8 \\
\hline \multirow[t]{2}{*}{$\mathrm{Na}_{2} \mathrm{O} / \mathrm{MEO}$} & $\mathrm{dd}$ & 0.5 & & 1.10 & \\
\hline & $e e$ & -5.5 & & 1.08 & 1.09 \\
\hline \multirow[t]{3}{*}{$\mathrm{G} 20$} & aa & 1.0 & 1.7 & & \\
\hline & $\mathrm{bb}$ & 8.5 & 2.7 & & \\
\hline & $\mathrm{cc}$ & 2.0 & 1.7 & & \\
\hline
\end{tabular}


QABL: VIIT.

Results of Spectrographic Analysis of Corn han

\begin{tabular}{|c|c|c|c|c|c|}
\hline $\begin{array}{l}\text { oxide or } \\
\text { xide Ratio }\end{array}$ & Curve & $\Delta I$ & oxide & $\begin{array}{l}\text { sulde } \\
\text { netio }\end{array}$ & Average \\
\hline \multirow[t]{2}{*}{$\mathrm{CaO}$} & $\mathrm{dd}$ & 2.0 & 2.0 & & \\
\hline & ef & -0.5 & 3.2 & & $2.3 \%$ \\
\hline \multirow[t]{3}{*}{000 / $\mathrm{MgO}$} & na & -1.0 & & 0.17 & \\
\hline & $\mathrm{bb}$ & -1.0 & & 0.19 & \\
\hline & $c o$ & 0.0 & & 0.18 & 0.18 \\
\hline \multirow[t]{3}{*}{ ingo } & $b b$ & 1.5 & $1 \% .0$ & & \\
\hline & $d d$ & 0.0 & 14.2 & & \\
\hline & ff & 2.5 & 15.0 & & 14.4 \\
\hline Lgo / CaO & $c e$ & 1.0 & & 4.5 & 4.5 \\
\hline \multirow[t]{4}{*}{$\mathrm{Ne}_{2} \mathrm{O}_{3}$} & ae & 1.0 & 1.0 & & \\
\hline & $\mathrm{bb}$ & -2.0 & 1.8 & & \\
\hline & 2 & 7.5 & 0.98 & & \\
\hline & BE & 4.5 & 1.05 & & 1.06 \\
\hline \multirow[t]{4}{*}{$\mathrm{He}_{2} \mathrm{O}_{3} / \mathrm{CaO}$} & aa & -3.0 & & 0.28 & \\
\hline & $\mathrm{cc}$ & -2.5 & & 0.248 & \\
\hline & $\mathrm{da}$ & -4.0 & & 0.277 & \\
\hline & $B E$ & -3.0 & & 0.277 & \\
\hline
\end{tabular}


WABLE VIII.

Results of Spectrogrephic Analysio of Corn Ash

\begin{tabular}{|c|c|c|c|c|c|}
\hline $\begin{array}{l}\text { Oxide or } \\
\text { Oxide Ratio }\end{array}$ & Curve & $\Delta \mathrm{L}$ & $\stackrel{f}{P}$ & $\begin{array}{l}\text { Oxide } \\
\text { Ratio }\end{array}$ & Average \\
\hline \multirow[t]{2}{*}{$\mathrm{O}_{2} \mathrm{O}_{3} / \mathrm{CaO}$} & $\mathrm{mm}$ & 5.5 & & 0.228 & \\
\hline & oo & 4.0 & & 0.236 & 0.253 \\
\hline $\mathrm{No}, \mathrm{O}_{3} / \mathrm{ing}$ & $\mathrm{bb}$ & -1.5 & & 0.08 & 0.08 \\
\hline \multirow[t]{7}{*}{$P_{2} O_{5}$} & aa & 0.5 & 36.6 & & \\
\hline & bo & -2.5 & 23.7 & & \\
\hline & $\mathrm{cc}$ & -0.5 & 24.2 & & \\
\hline & $\mathrm{dd}$ & 0.5 & 25.2 & & \\
\hline & $f f$ & 3.5 & 25.4 & & \\
\hline & $j$ & 2.0 & 22.8 & & \\
\hline & 11 & 2.0 & 22.1 & & $2 \pi .3 \%$ \\
\hline \multirow[t]{6}{*}{$\mathrm{P}_{2} \mathrm{O}_{5} / \mathrm{CaO}$} & $\mathrm{co}$ & -3.5 & & 8.6 & \\
\hline & dd & -3.0 & & 8.7 & \\
\hline & ff & -0.5 & & 0.8 & \\
\hline & $j j$ & -0.5 & & 9.0 & \\
\hline & kk & -3.5 & & 9.9 & \\
\hline & 11 & -0.5 & & 8.2 & 8.9 \\
\hline \multirow[t]{2}{*}{$\mathrm{P}_{2} \mathrm{O}_{5} / \mathrm{M}$} & ae & 0.5 & & 1.80 & \\
\hline & $\mathrm{bb}$ & 1.0 & & 1.70 & 1.75 \\
\hline
\end{tabular}


In Table vIII are tabulated the data secured from the spectrograns of the grain ash. The constituent or quantitative ratio is given, letter designation of the Iine pairs used in determinetion of the percentrges or ratios from the operating curves are indlcated, the corresponding values of $\Delta I$ for those line pairs, and the deterained ralues and their averaces.

A sumnation of these results appears in Table IX. 
RUSULTS 
Direct current was found to be preferable to lternating current (110 volts) for excitation of the arc. Although the alternating current was convenient for adjustnont and test operations, the are was difflcult to malntain and material was lost from the sample by sputterine. By use of the direct current a steady and easily burning arc tras formed, and the spectrum produced was moh more intense and shoved finer struoture. Furthermore, the spectroGraphically pure carbons vould operate only on direct current.

It was found that the voltage aro across the arc was most neerly constnut when it represented but small portion of the potential arop of the circuit. For this reason the generators were opereted at maxirnm voltage delivery, and a total resistance of about 35 ohns incorporated in the circuit, exclusive of the arc. The voltage aro across the are gap at maximum vidth was about 60 volts and the current was 6 to 8 amperes.

the arc showed a marked tendency to wander about the pole tips, causing a variation in voltago drop across the gap and at the sme tine producing undesirable fluothations in current. This as substantially reduced in several ways. Hirst, by use of a wide arc gap the ability of the are to wander ves greatiy diminished. Second, the 
Iover polo tips wero ground carofully to an even edge about the periphery of the crater, and the upper electrode vas pointed and carefully centered over the lowew one. Inally, an inductance of about I henry was obtained in the circuit by adaing a primary ojil of a transformer in series. slight voriations in the position of the are Ilane continued to cause the image to shift across the face of the grating a diffusing reflecton was trion with succoss. Fits was a polished stoel plate, bumished in parallel vertical lines. Placed on the optical axis at a large angle of incidence, it served to reflect diffused light from the are indirectly to the optical system. lowever when a second lens vas omployed to project a long hori zontal image of the ere flame acros the slit, the slight vandering of the tlane was of no significance.

Barly in the experimontal stage the operators discovered thet the focal length of the replica erating varled considerably with appreciable change of roon temperature of humidity. The nicrometer screw, previously described, afforded a convenient means for accurately adjusting the position of the grating.

A number of modifications of the optical system vere tested. The method for obtaining the conbination of conditions found to be optirnu has been desoribed under the 
method of procedure. The arrangement of the component verts of the system is shom in Figure 3 .

The optical axis wos $23 \mathrm{cr}$. above tho track, corresponding to the ecnter of the portion of the slit opening employed. The aro gap, shield vindow, and both lenses vere centered upon it. The distances of the spe and lenses from the slit were 65,51 , and $35.5 \mathrm{~cm}$. repoctively. As previously described, the sano with of arc gap wes obtained for eac exposure by aliening the bright Iine of the pole spots in coinciaence with the chnll Iines dratn on the face of the instmment housing.

results of teste made to detemine the ontinum condtions for duration of exposure and time of development are shom on the foll wing page. n exposure of 30 seconds duration did not give suficient detall, whereas a minute's exposure was satisfactory in this respect, but showed increasing background. Naxtrum denstty of the Ines was desirable, but fouging is indlcated beyind a d veloping time of 3.5 minutes, $x$ combination of 45 seconds ex posure and 3 minutes d velopment timo vas seloctod. From an observation of the figure this selection might eppeer doubtrut, but the prints for that set of conditions wore from the infre-red region of the photographic film, and actualiy show comparatively good results. 


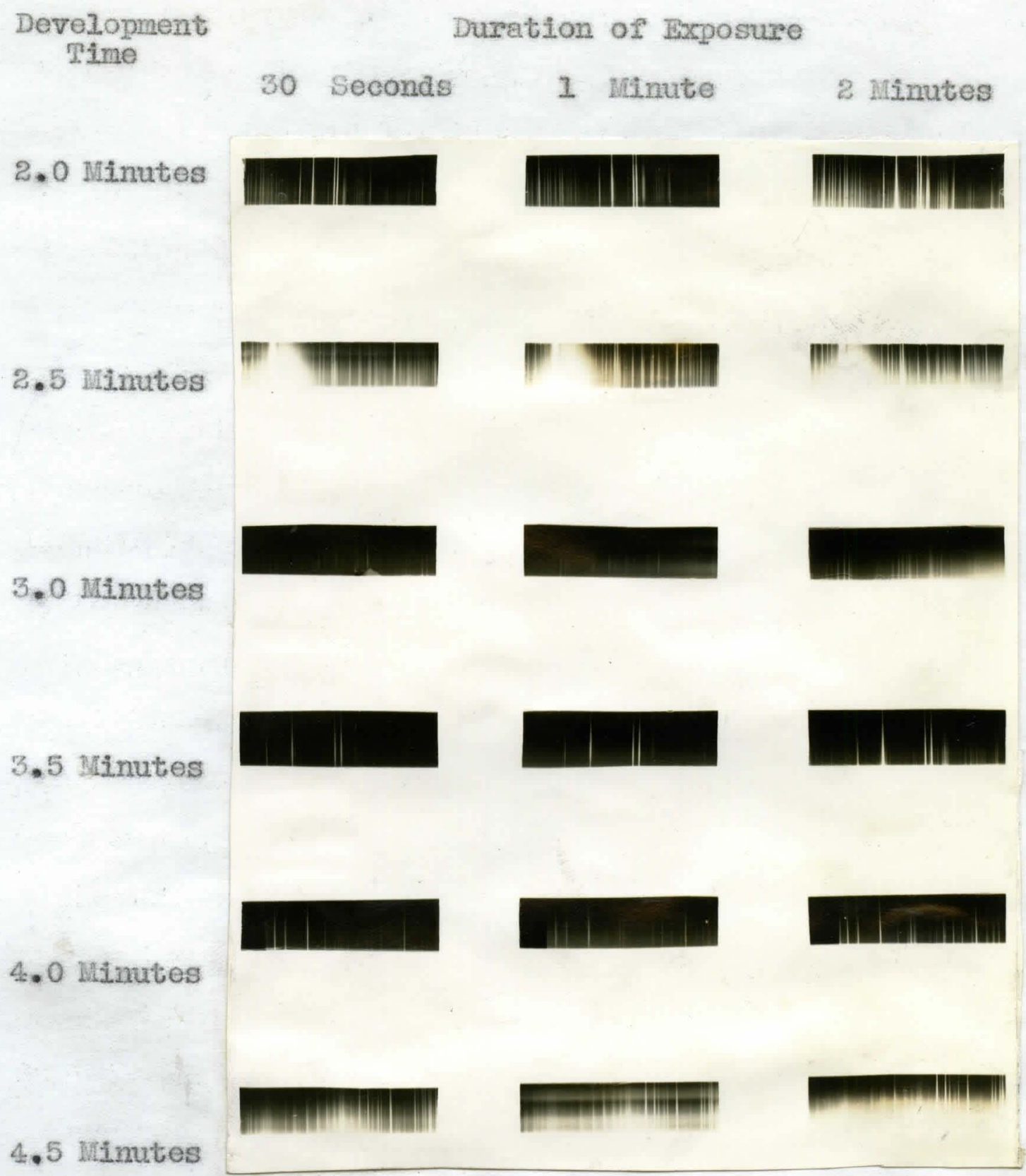

Fig. 7 Jffect of Duration of Bxposure and Development Time on Quality of Spectrograms 
It was learned that a dovioper temperature of 15-160 was necossary to prevent sliding or broaking of the omlsion. Iso, addition or small anounts of acotic coid to the hyo fixine bath had a desirable herdening erfect on the golntine.

of the thirty-six standard aixtures, several were unovolabiy lost in the preperetion and could not be re placod.spectrograms vero mas of those complotod. A typical guantitative spectrogram is shown in Difuro 6 . Deonse the print 1 serersed fron the negative, the wave-1oncths docrosse in magnitude fron lort to right. The vodge shoped appearance of the lines $x y$ be obserred, and also wis tendency of line lines to continue from the apperent point of termination completely across the syectrogran stip.

The nerrow band of continuous exposure alloved in setting the elevation of the logrithic sector is uite plain at the botton of each spectropran. The lenctho of the Iines vere neesured from the very bottom of the spoctrogran and the difforences computed. The continuous brint whte bands are coused by cyanogen, and occur in the violet portion of the pectrum.

pon onlergonent vith e projector, the lines of the spectrograns were eas iy identivied, and the lengths were weasured in units of $1 / 4$ inch. Wis corres onded to 
$1 / 32$ inch on the filn. The oratine we of bood quelity, and ajust cents used gavo excellent res lution of tho lines. nalytiod curves are shom in the following six ricures. The ordingtes are values of tho difforencos or lengths of partioular ino peirs, the vavo-Iengths of hich are tebulatod below the rigures. The abscissae represent the ratios of the anute of the oxides of tho particular elewent and the ho. Since the nolybdenm is presont in the nixture in constant amount, the percentage of the particular oxide, or varica constituent, was plotted directly.

It has boen customary to ropresent line poirs as a ratio. Tor exanple, $\mathrm{E} 3446$ / No 2000 . AI is tho difference in lencthe of th se two lines, and vill depend upon the onount of $\mathrm{I}_{2} \mathrm{O}$ in tine mixture or samplo spootrogrephed. ictually, as explained in tho thoory, $\Delta L$ is a function of the relative mounts of the tro substances, cono the representetion as a ratio.

Sone of the curros, wen $2 \mathrm{~s}$ those of $\alpha$, are based up n lines which ere easily reversed. Potassiun linos in tre cro spectmu wion co not show reversal are mare, and it wes necessery to attenpt use of the others.

Assuning thet the len the of the nolyodemun Ines remined constant, it would be obvious, then, thet the Iengthe of the potaselum lines, of the intensisy of tho 
radiation of potassium in the are, decreased to a minimum at a concentration of about $25 \%$ and rose again to a higher velue.

boviously a difficuty arises if these curves retrace their ordinate range symetrically. It hient be possible in the anelysis of an ash sample to find differences in lenths for line pairs such that two sots of values are found for the percentage of one component. If the values for each set checked, the analyst inight find it necensury to further dilute the sample and respectrograph it. Actually such a case did occur twice. However, by roserenoe to the retio quantitative ourves, and thereby indirect reference to the anounts of cao and 1400 detomined without difficulty from straisht line functions, the correct set of values vas established.

Tor tho coordinate systen used, it shma be propex for ench curvo to proceed up nad torapd the right. However, somo of the Iines divnay a negativo slope. This nay be partly explained by voakening of the line inteneity caused by partiel reversal. 


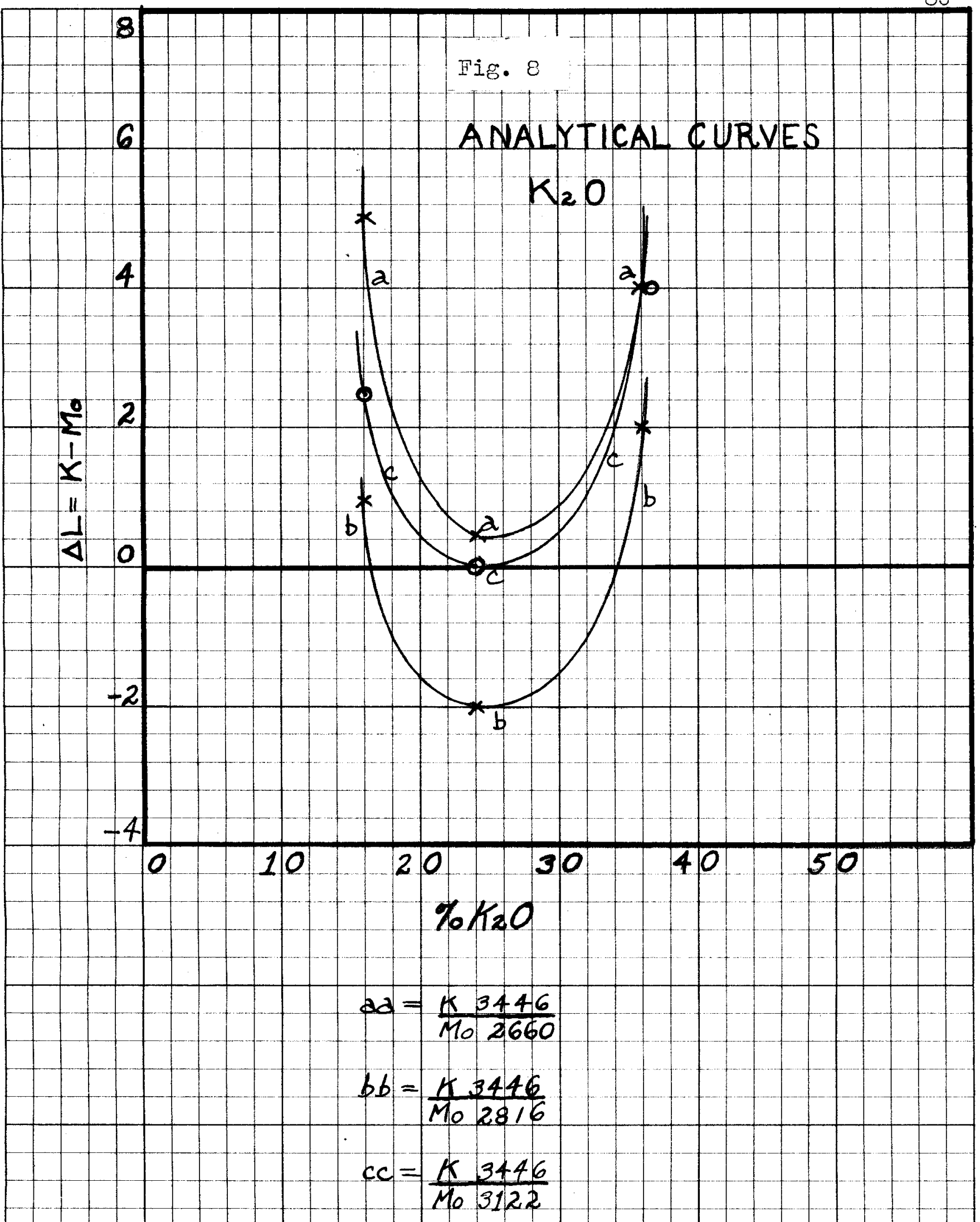




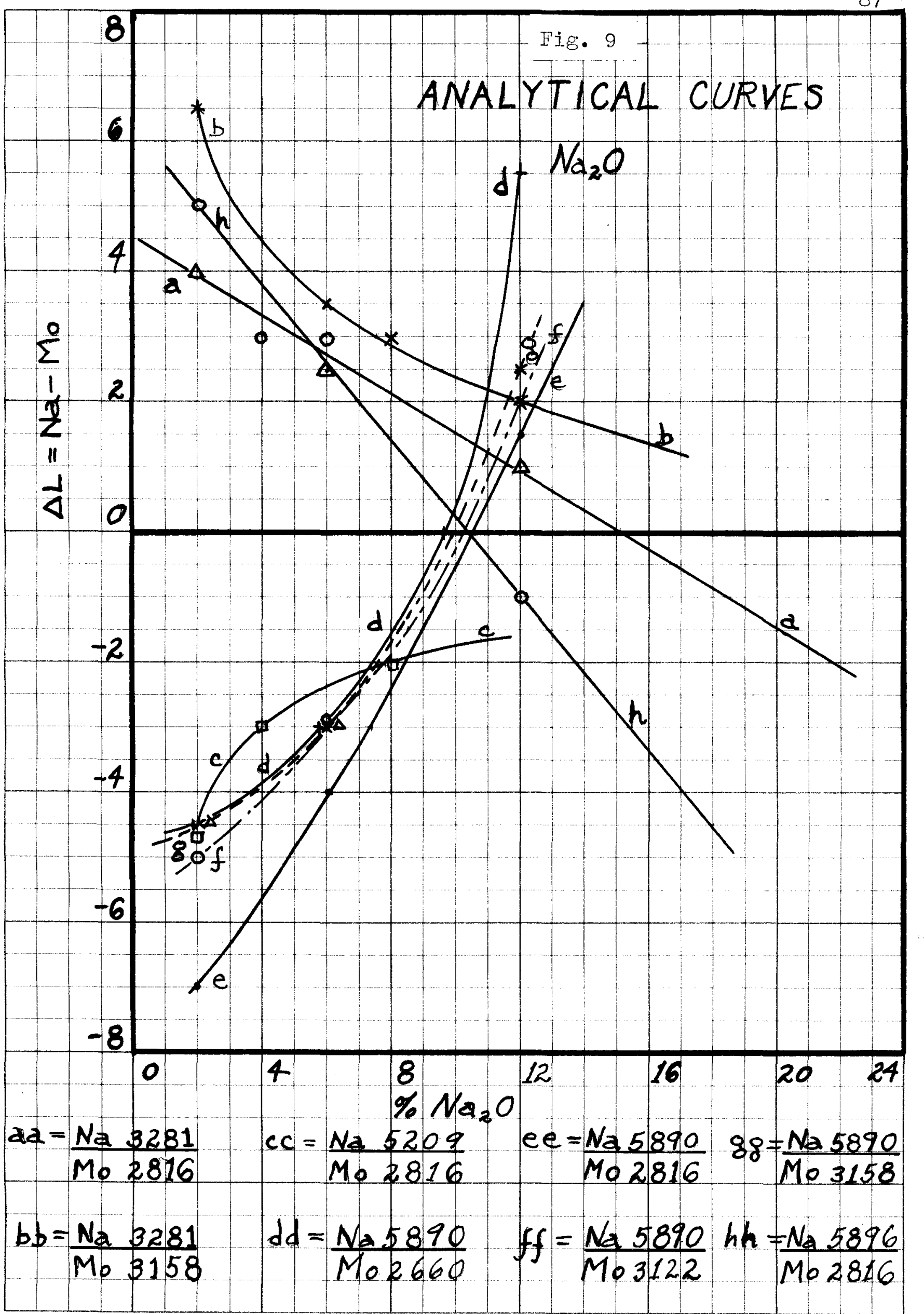




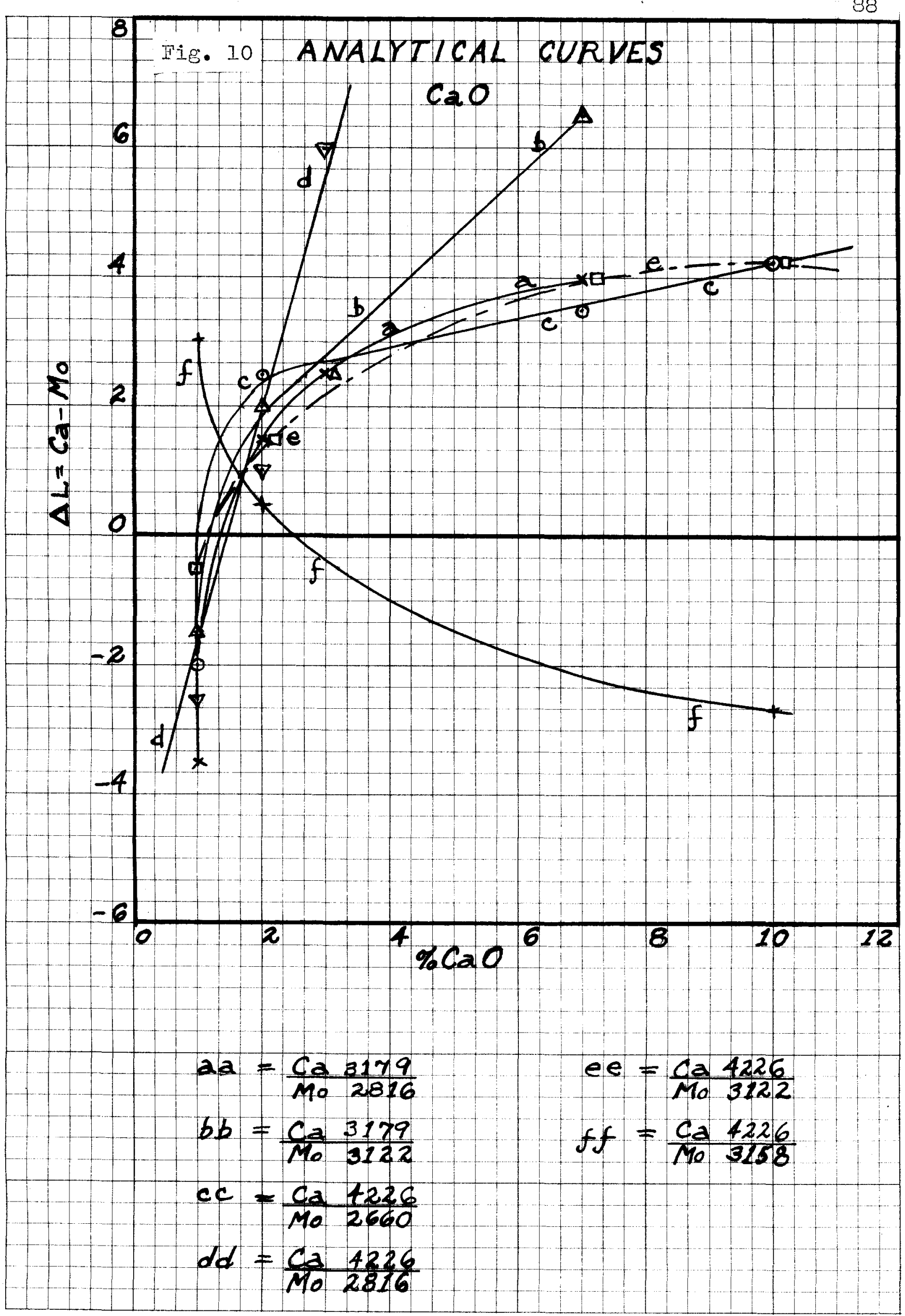




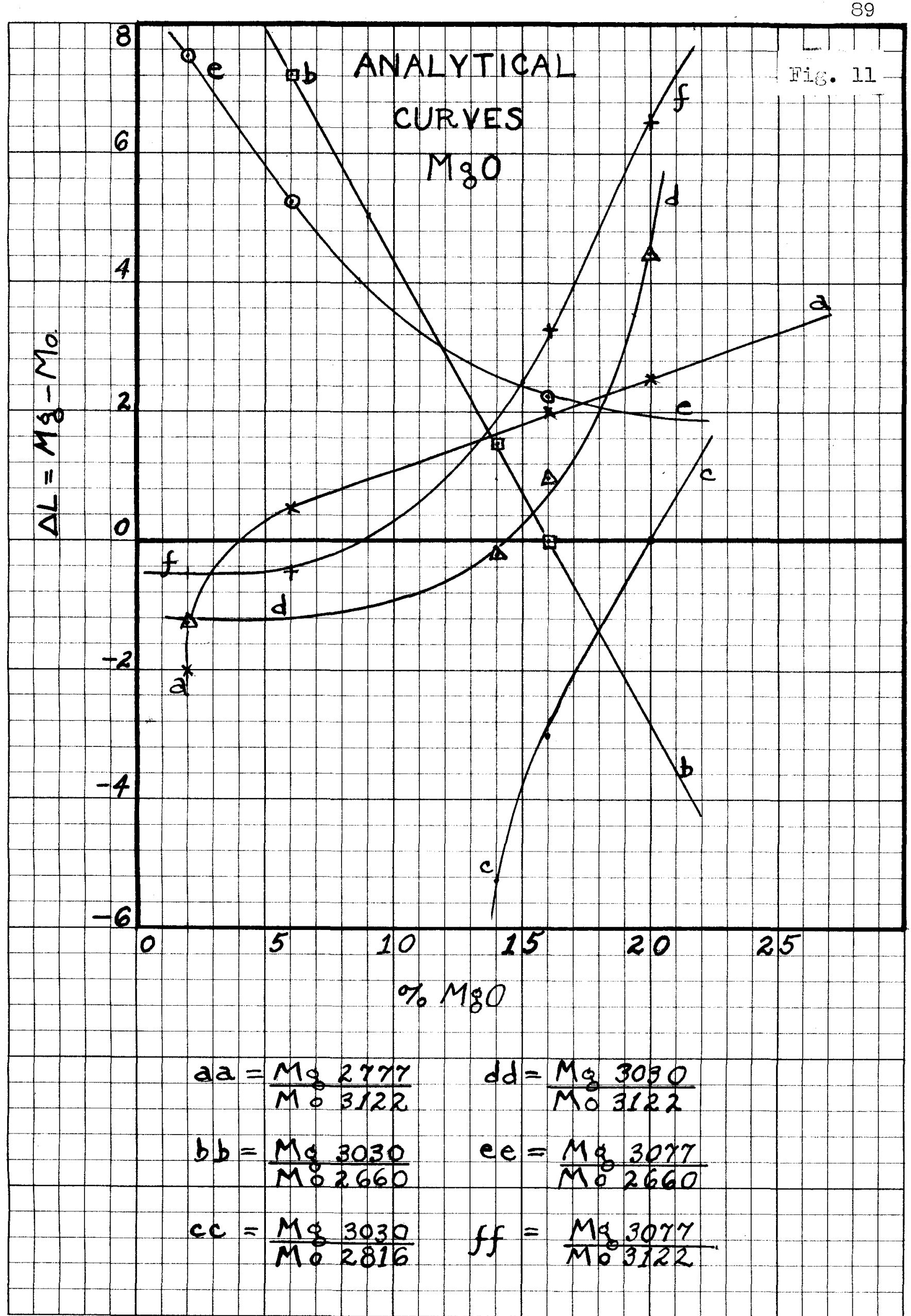




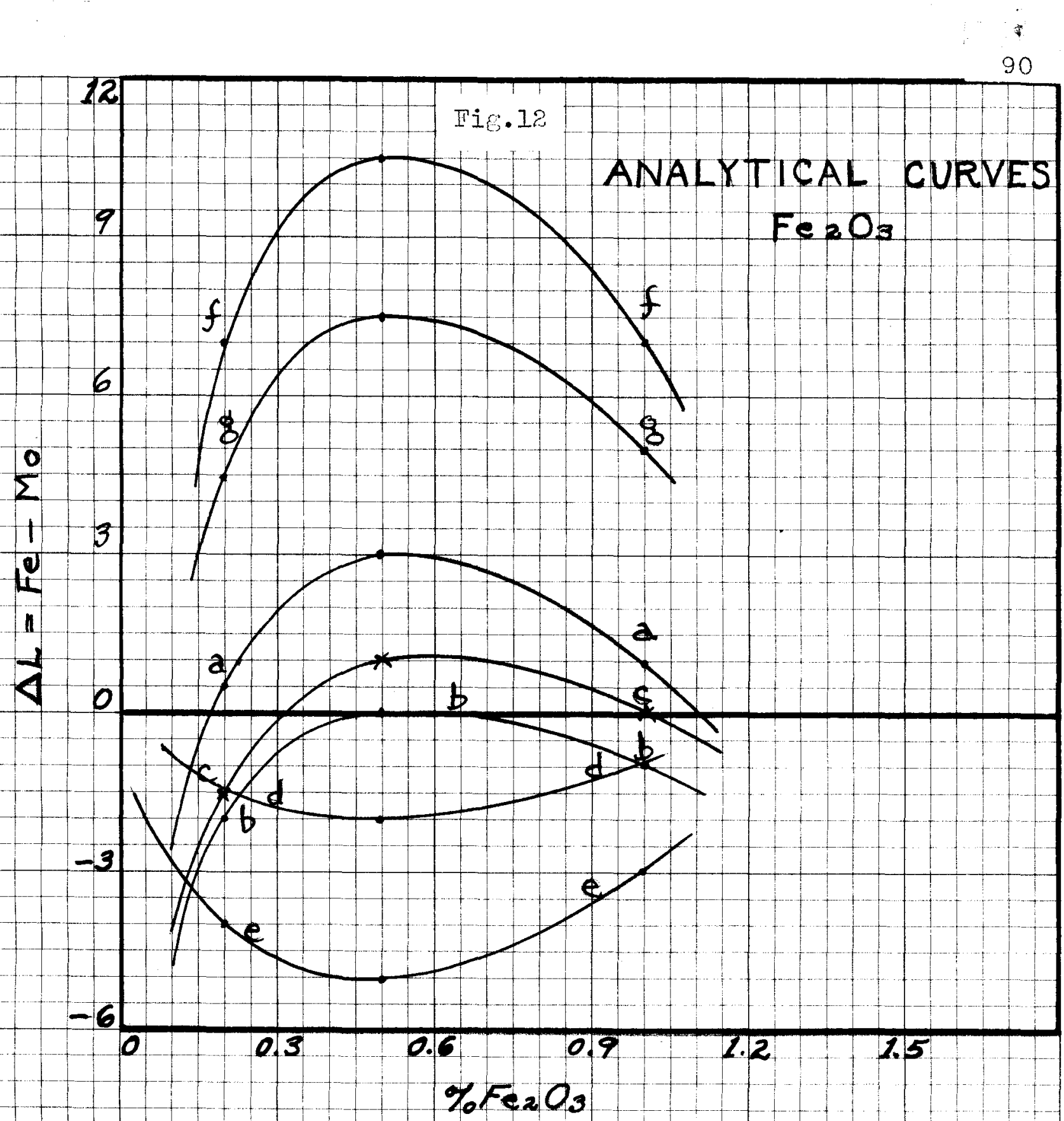

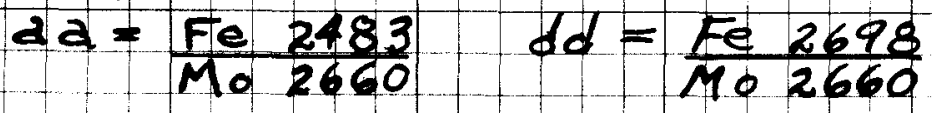

$$
\begin{aligned}
& b b=\frac{F_{e} 2483}{M 02816} \quad \text { ee }=\frac{F_{e} 2698}{M 02816} \\
& c c=\frac{F e}{M 02599} \quad f f=\frac{F e s 020}{M 02660} \\
& g o=\frac{F e}{10280}
\end{aligned}
$$




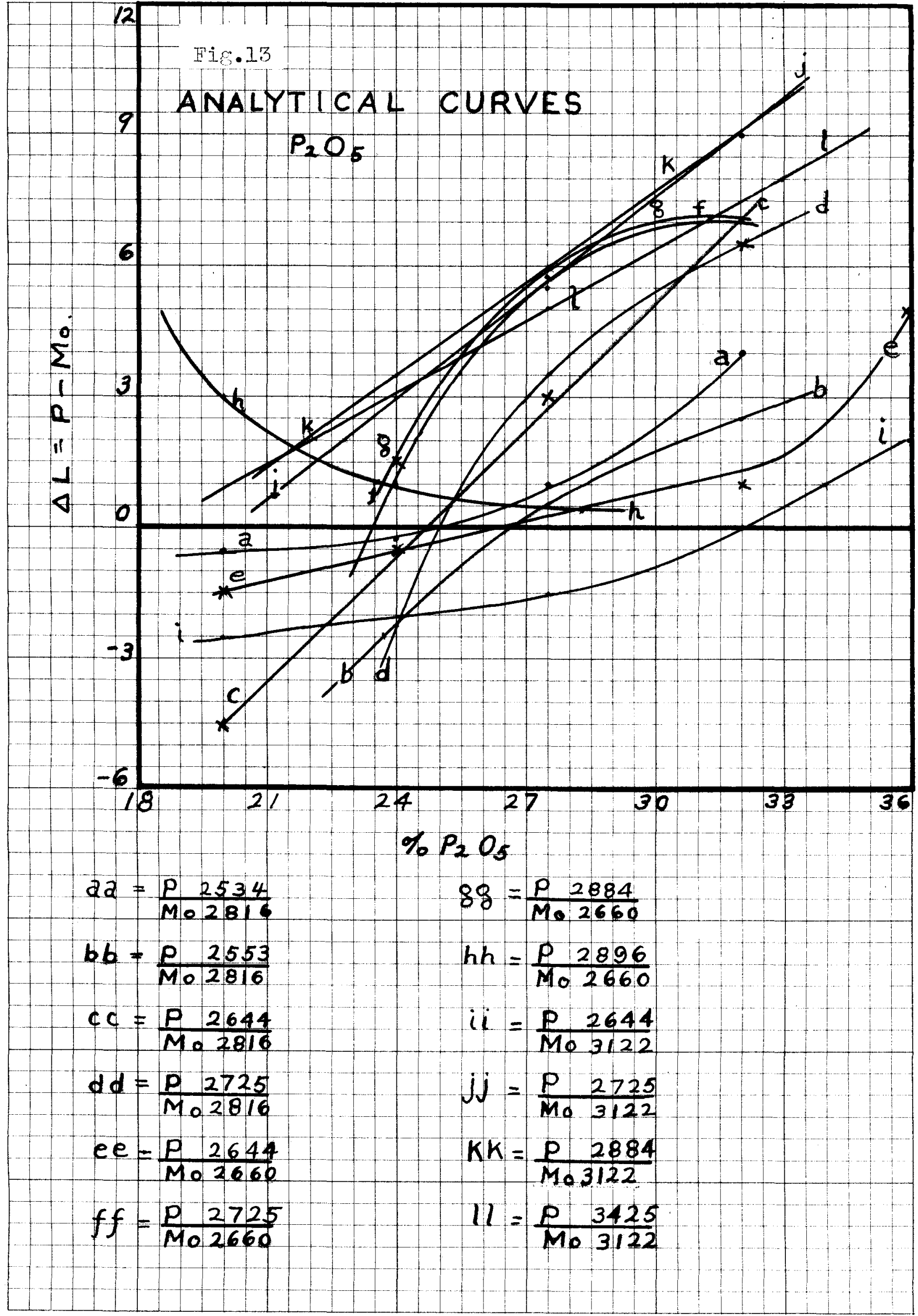


In the rollowing Igures appear the ratio quantitative curves. Of each line peir indicated, one corponent vas a spectral line of the varied constituent and the other a line of either magnesium or calclum. I degignated the magnitude of the differences of lengths of the two lines.

Tho abscissar are the ratios of the concentrations of oxides of the varied constituents to those of hig or Cao. Since hoth are variable, the percentage of the variod oxide could not be plotted directly. These ratios vere calculated from the data tableg for the composition of the standard mixtures.

actually there was no absolute method of detemining which of these lines or curves might have arisen from error or chence, elthough agreement of values in anelysis of the grein ash gave sone clue to this.

For determining the amount of an oxide or the ratio guantitative value of that oxide in the spectrograhed ash, the $I$ for tho given line pair was obtained from the data for the ash spectrogram, and the abscissae determined, A few values vere not in agreement vith those obtained from the majority of the curves, and these vere rejected as being due elther to error in measurement of the length of a line in that pair, or to an exroneous curve. 
$9: 3$

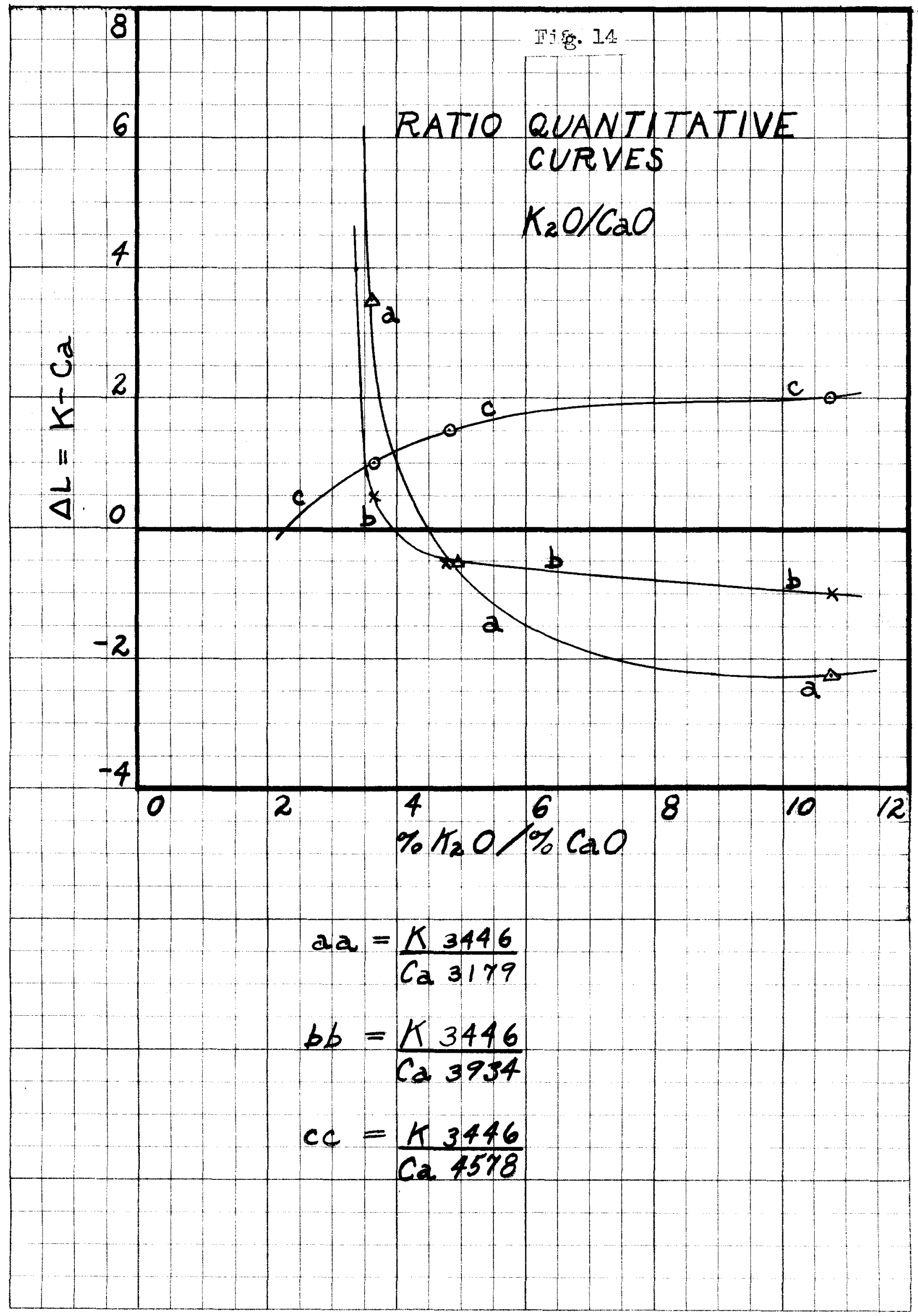




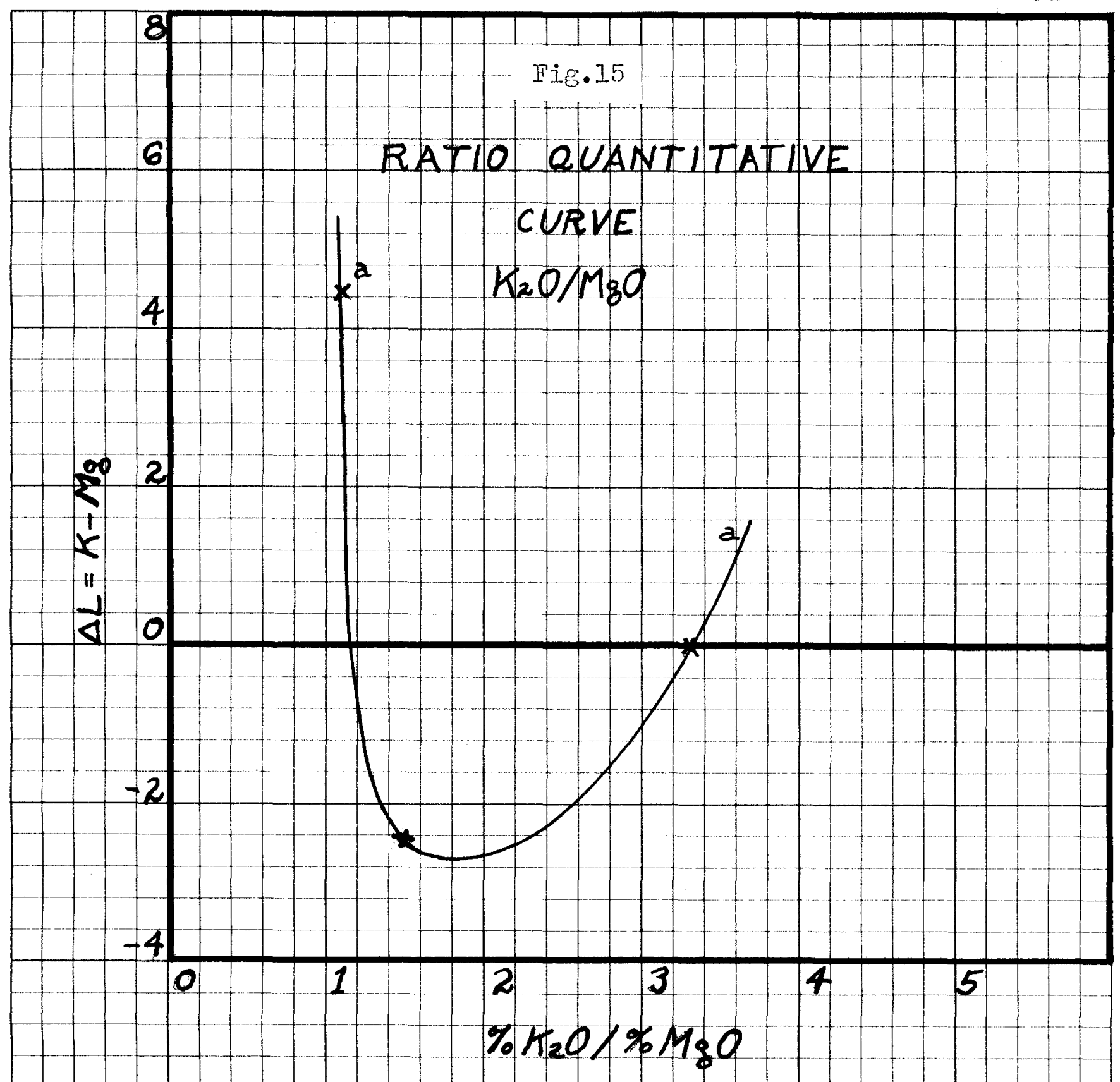

$$
2 A=\frac{K 3446}{M g 3030}
$$




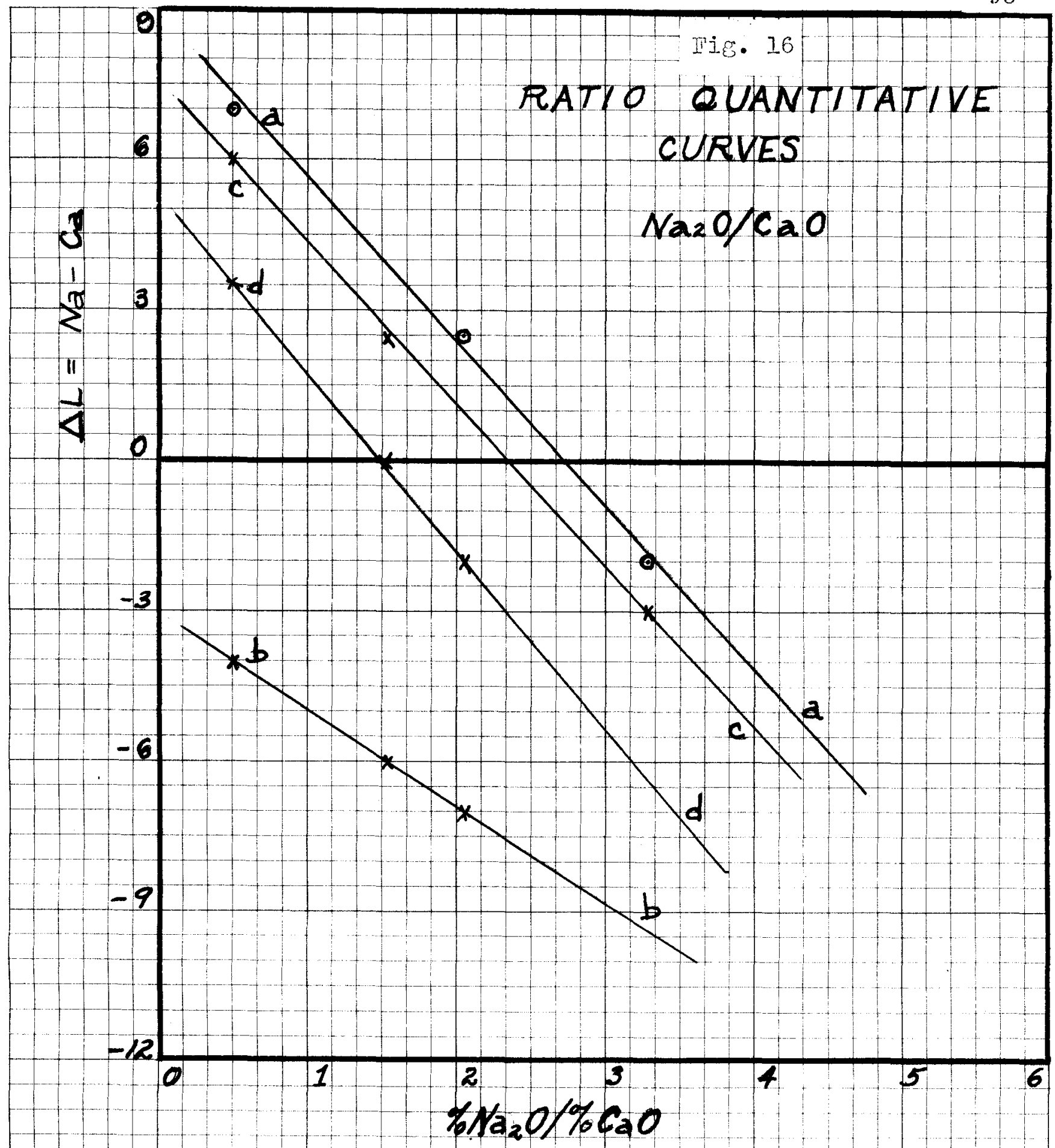

$$
\begin{array}{ll}
a a=\frac{N a 3781}{c a 3179} & c c=\frac{N a 5896}{c a 3179} \\
b b=\frac{N a \cdot 5209}{c a 3215} & d d=\frac{N a 5896}{c a 3215}
\end{array}
$$




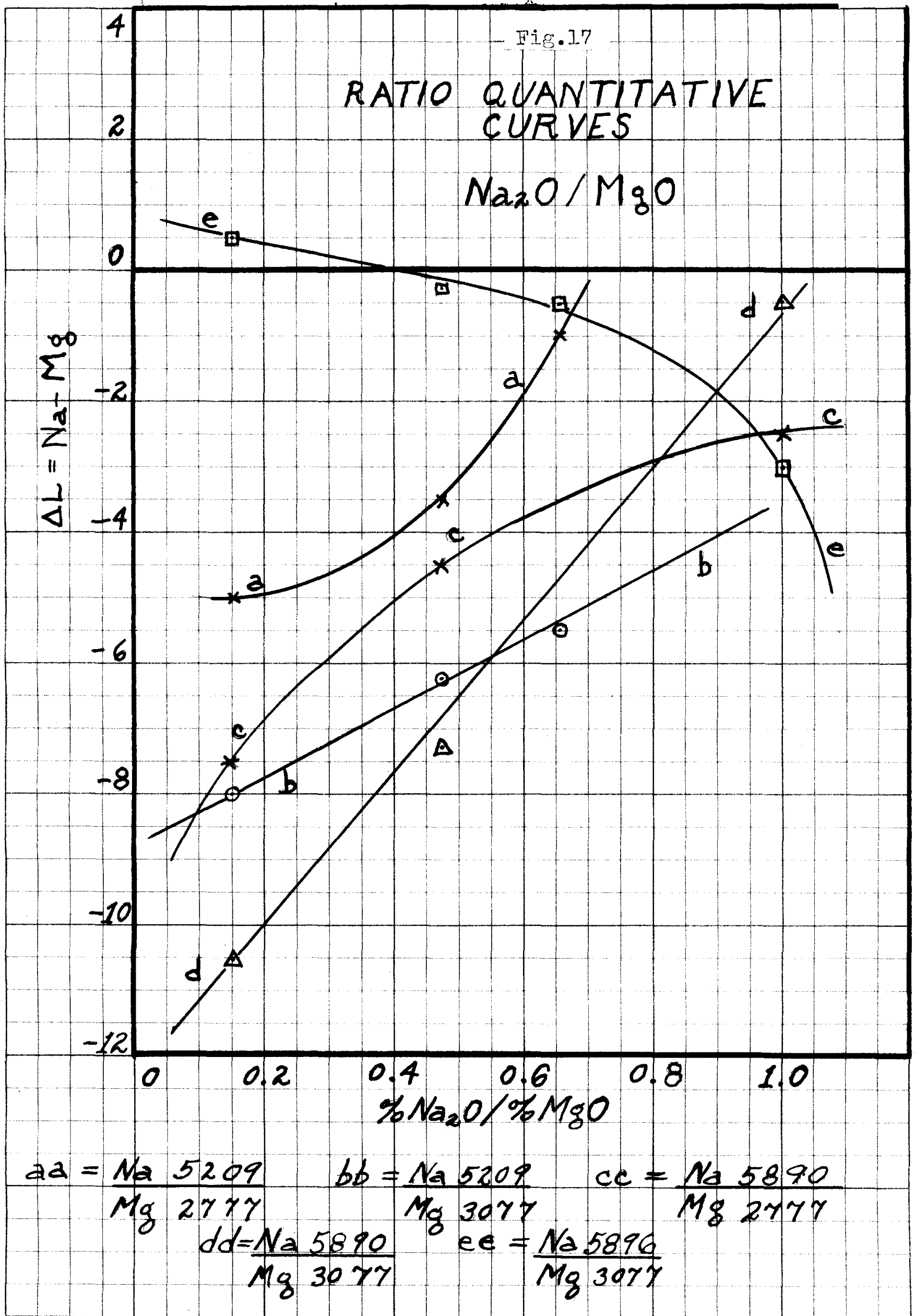




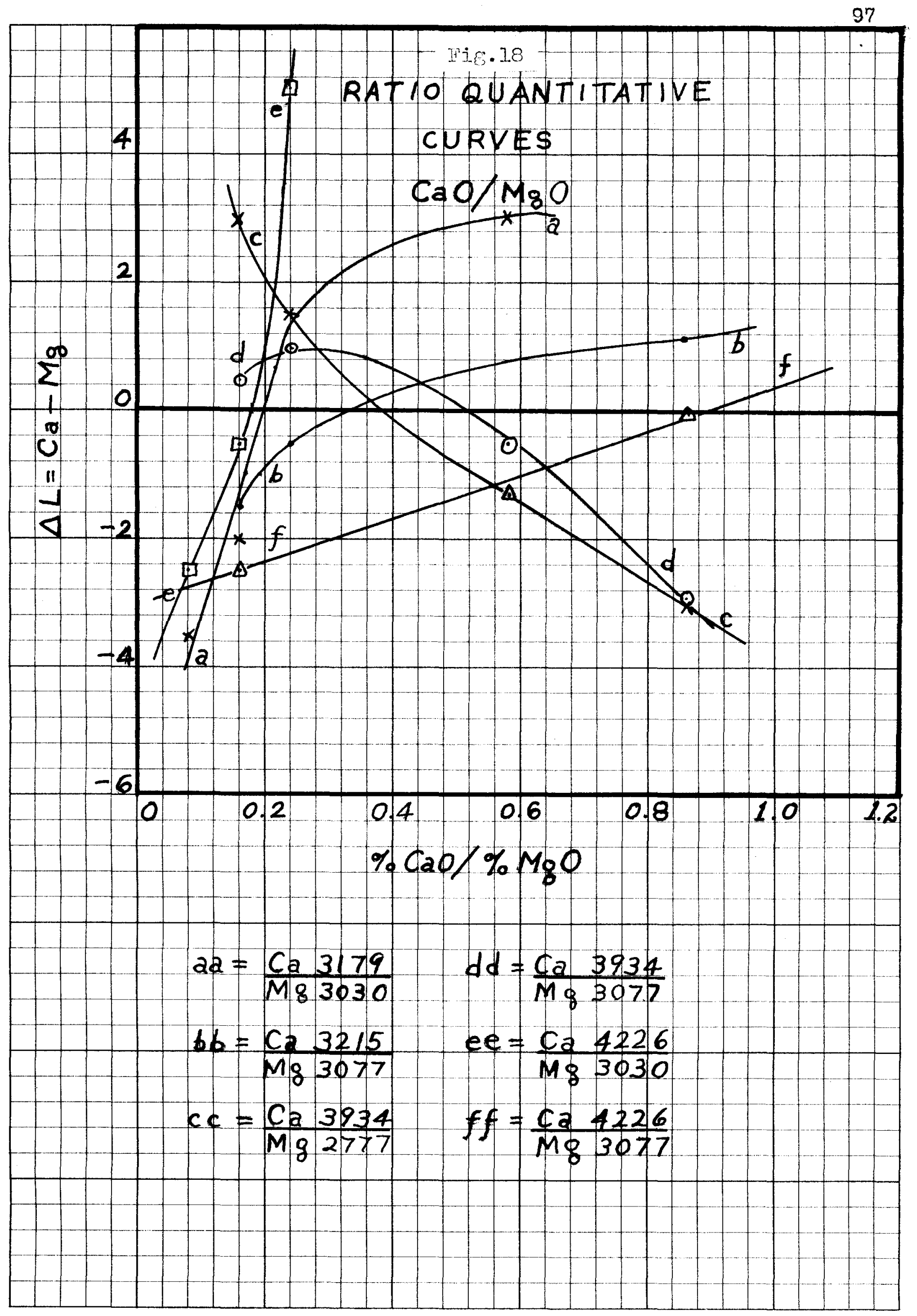




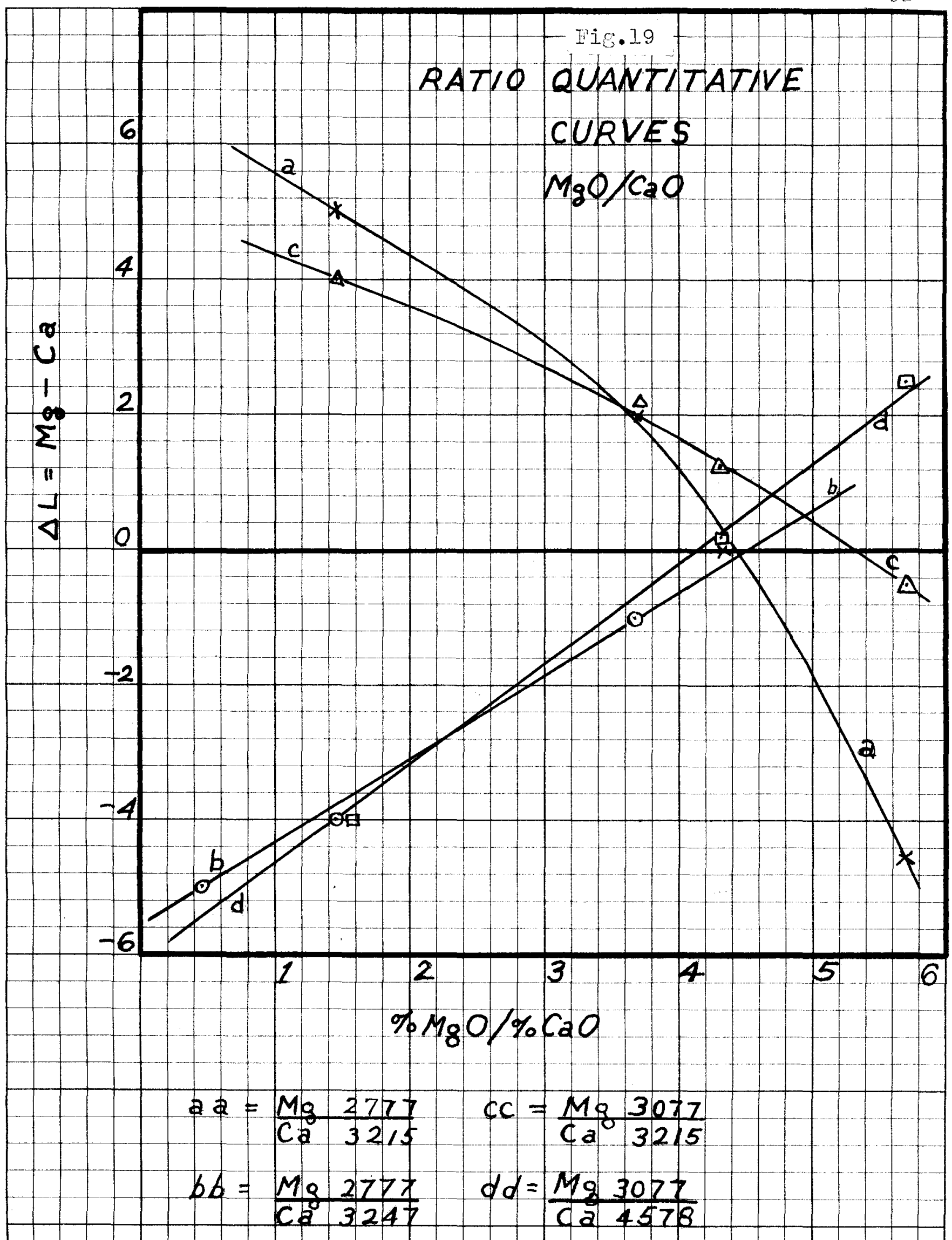




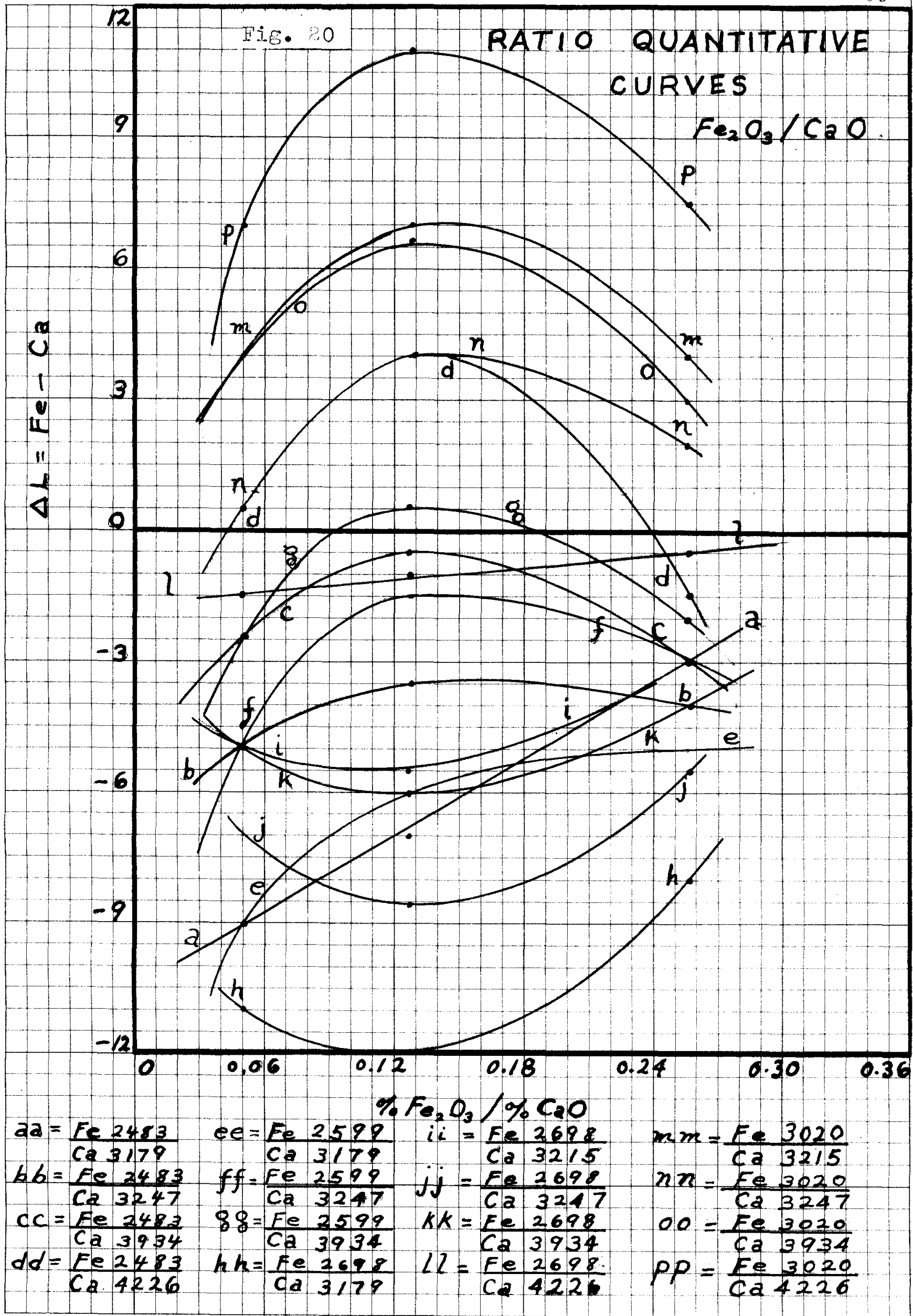




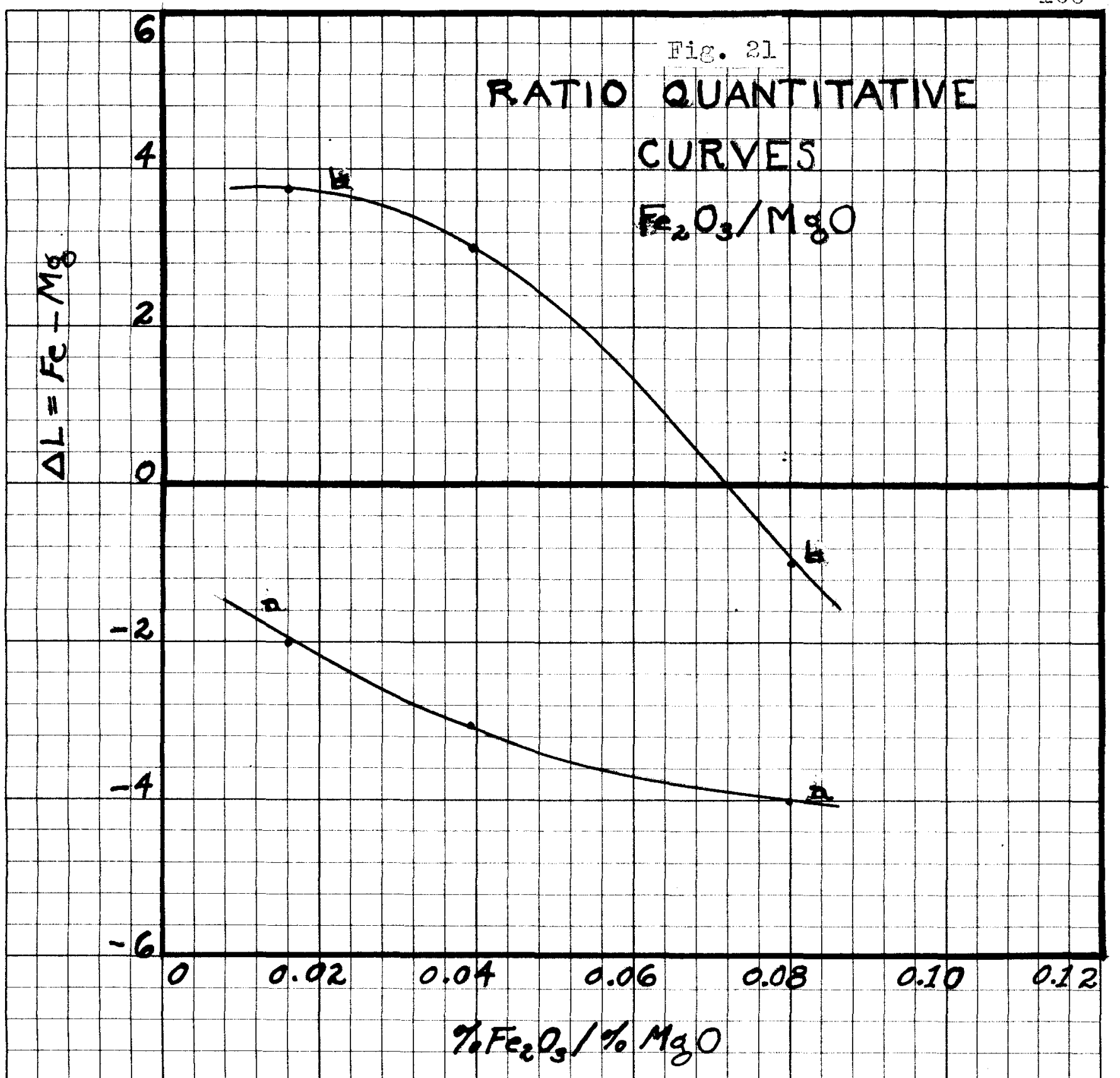

da $=\frac{F_{e} 2483}{M 83030}$

$b b=\frac{F e 3020}{M g 3071}$ 


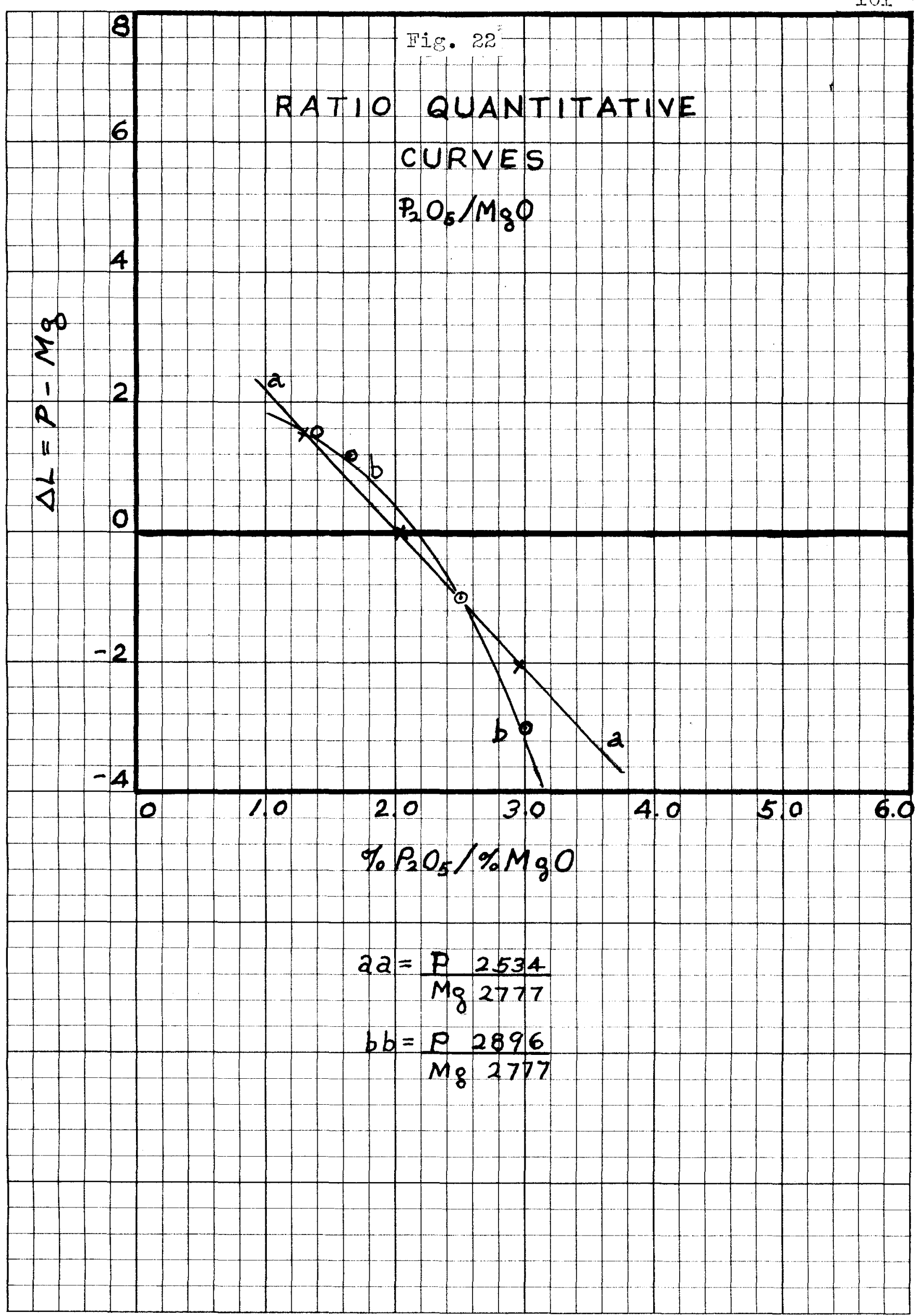




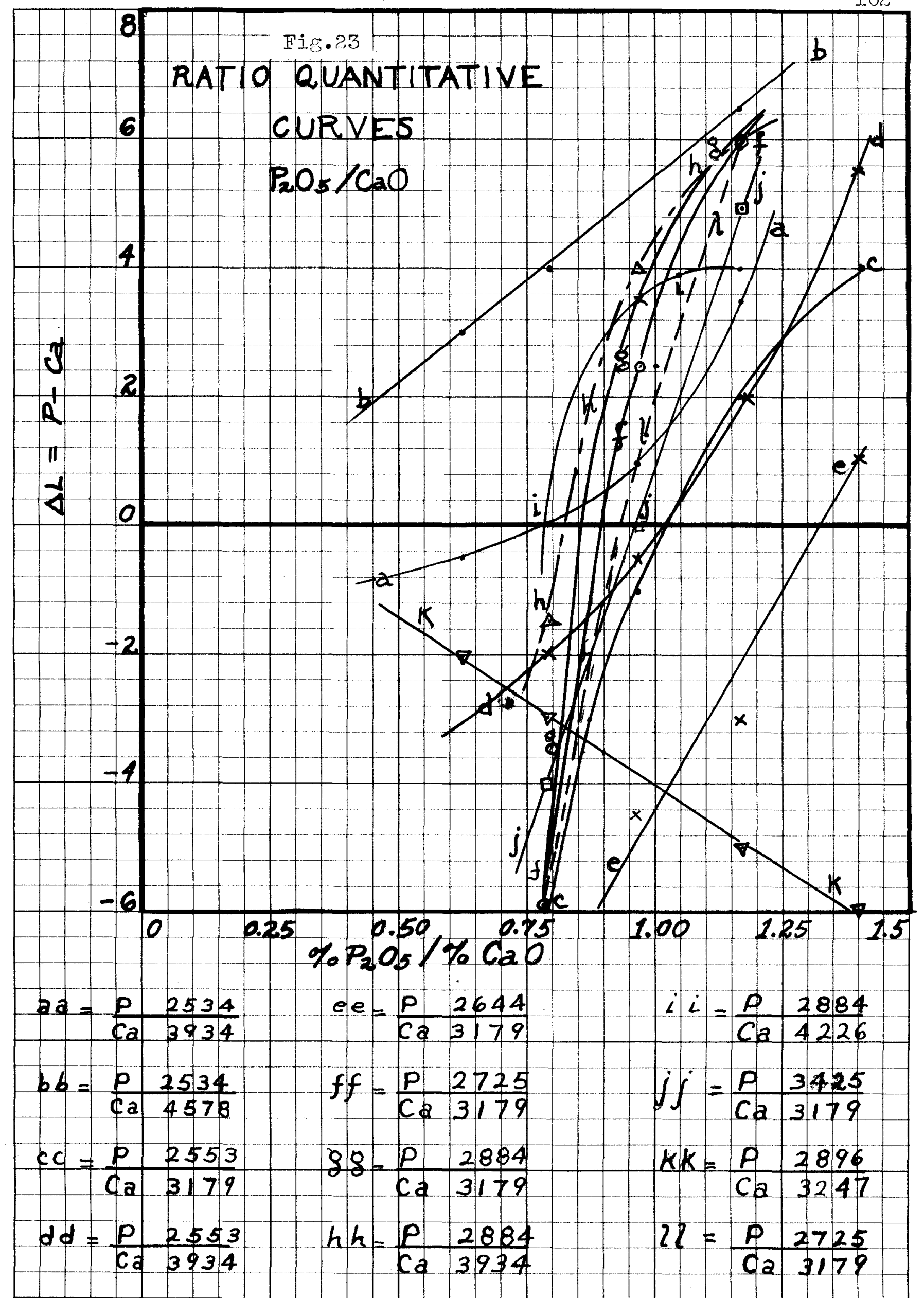


The results of the spectrographic analysis of the corn ash sample prepared are shown in the table on the following pne. The ash semple was photographed in duplicate, but photographic difficulties in obtaining the second spectrogram rendered some of the lines ind terminate.

The values of $\Delta L$ and the corresponding values of percontages of the oxide constituonts and the quantitative ratios are given in. Table VIII.

For the ratio quantitative systom based upon $18 \mathrm{~g}$, the value of Mo detemined on the basis of tho $(14.4 \%)$ was assumed to be correct. lor that based upon CaO, a value of 3.5, Gao was assumed to be correct. This gave a total oxide content, exclusive of $\mathrm{S}_{102}$, equal to the average of the like contents of the other two detcrinations.

The percentage values based upon wo and higo showed excellent areement, but those based upon cao differed from the others appreciably. In almost every set of values for an individual percent, hovever, the values shoved ozcellent agrecment with their average. 
PABLIS $I$.

Calculated Composttion of corn Ash

\begin{tabular}{|c|c|c|c|}
\hline oxide & & 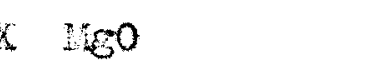 & X GaO \\
\hline$K_{2} 0$ & & 1.10 & 3.35 \\
\hline $\mathrm{Na}_{2} \mathrm{O}$ & & 1.09 & 2.8 \\
\hline ligo & & 1.00 & 4.5 \\
\hline CaO & & 0.18 & 1.0 \\
\hline $\mathrm{Fe}_{2} \mathrm{O}_{3}$ & & 0.08 & 0.253 \\
\hline $\mathrm{P}_{2} \mathrm{O}_{5}$ & & 1.75 & 8.9 \\
\hline $510_{2}$ & & & \\
\hline oxide & $\%$ & $\%$ & 9 \\
\hline & $($ ino $2.0 \%)$ & $(M 45014.48)$ & $(\mathrm{CaO} 3.5 \%)$ \\
\hline $\mathrm{K}_{2} \mathrm{O}$ & 15.0 & 15.8 & 11.9 \\
\hline $\mathrm{Na}_{2} \mathrm{O}$ & 15.5 & 15.7 & 9.8 \\
\hline $\mathrm{MgO}$ & 14.4 & 14.4 & 15.9 \\
\hline $\mathrm{CaO}$ & 2.3 & 2.6 & 3.5 \\
\hline $\mathrm{Fe}_{2} \mathrm{O}_{3}$ & 1.06 & 1.10 & 0.99 \\
\hline $\mathrm{P}_{2} \mathrm{O}_{5}$ & 24.3 & 25.2 & 31.5 \\
\hline $\mathrm{SiO}_{\mathrm{g}}$ & 87.44 & 25.2 & 26.3 \\
\hline
\end{tabular}


108

SUMRARY 
A Cenco Replica Grating Spectrograph was assenbled, and accessory equipment added for convenience and accuracy in adjustment and operation. direot current are betwoen spectrographically pure carbons produced an emission spectru? of and substance placed in a cavity in the lower electrode. The curront required $w$ as 6 to 8 amperes. An aro gap of $0.5 \mathrm{~cm}$. was enployed, end an enlarged image of the are flame was produced on the slit and grating by moans of a quartz lens. 1 porbion of this beam of light was converged at the slit by a second lens, so thet the entire surface of the grating was covered. Use of quartz lenses permitted photography in the ultraviolet region.

The slit width was adusted to give maxinum sharpness and resolution of the spectral lines, ith mininwn background, without decreasing the intensity or the Iines. With the slit adjustiont usea, the optinum duration of exposure and time of develo ment vere found to be 45 seconds and 3 minutes respectively. number of synthetic ash standards wore preparal, corresponding in composition to an "everage ash". This was the average of the nineral analyses of twelve different representative grains, reduced to the basis of a total of $100 \%$. The constitunts of the oxide ash were $\mathrm{K}_{2} \mathrm{O}, \mathrm{Na}_{2} \mathrm{O}$, 
$\mathrm{Hig}, \mathrm{CaO}, \mathrm{Ye}_{2} \mathrm{O}_{3}, \mathrm{P}_{2} \mathrm{O}_{5}$, and $\mathrm{SIO}_{2}$. For each of the oxides excent the last there was a sories of six mixtures, in which the amount of tho partioular oxides varied between the lower and upper linfts of the expected range of analysis.

The standard mixtures were repared volumetricalIy from sulfates of the constituents, except $\mathrm{Ca}$ and Si, and an anount of ammonfum sulfate added equal to the weight of the sulfate residue. Fto percent of molybdenum, relative to the total oxides, was added in the form of ammoniun nolybdate solution, to serve as the internal standard. The molybdenum fumished lines sufficiently close to those of the test elonents to serve as an internol standard for all, and at the sane time of such intensity that one spectrogram served for andysis of all those elements. The solutions were evaporated to arymess, being atirred the whlle to insure homogeneity, and the residues ground to fineness. Ground com was ashod in the presence of nitric acid and an exoess of sufuric acid to reduce the nineral content to a condition approxinatine normal sultetes, homogeneously ritzed with pro-existine silicates and phosphates. A representative ash sample was nixed with an equal weight of amoniun sulfatc and the correct anount of anmonium nolybdate for spectrographing. 
The amples for spectrogrophing vere cornessed into cavitieg drilled in the ends of the lower cribon eleotrodes. Uxposure vas begun imodiately when the cre was struck, and tho omount of sanple used was such the durine the time of exposure it ws alnost completely, is not entireIy rolatilized. Thus the complete record every constituent of the sanple was obtained.

A study wa made of the Internal. Staniar nethod of Cerlach, and of the Ratio cuantitative system devised by Lewis. In the first method, the nolybdenum serted as a roference standerd, end in the second, the oxide constituents were deter ined relative to the roo an cao present.

A rotating logarithnic sector disk vas usen before the slit openine, by virtue of which the lengtha of the spectral lines of the various elements vere a function of the logarithn of the ratio of their intensities, and consocuently a direct runotion of their relative amounts.

Ines recomonded in the ifterature or chosen

fron gualtative spectrogrems were used. in enlarged inage of onch spectrogran wes projocted onto a scroen, the proper Ilnos identified, and their lengths nensured.

perating curves were tho: established for each Iire pair, showing the relation between differences of lengths of the two lines and the corresponding relative 
a pounts of the two constituents represented. In oases in which molybdenum was the reference element, since its amount was constant, the concentretion of the other element could be plotted directly as percent oxide in the synthetic axide ash. Such a curve has been designated as an nalytical Curve.

Ratio uantitative Curves pere established on coordinates of differences of lengths of line pairs consisting of some element and either $\mathrm{Ig}$ or $\mathrm{Ca}$, and the corresponding ratios of the oxide of that element to ifgo or Cao. For any two elements there were a number of possible Iine pairs. Only those curves which were straight lines or appeared to be consistent functions vere retained. Some curves showed symetrical retrace of ordinate range, so that two sets of ralues for percentage of a constituent oxide could be obtained for a single set of values for I. This has been explained as the result of the reversal of lines of the partlcular constituent. However, wen such a condition vas encountered, by reference to the quantitative ratio curves, the amount of CaO and Ifgo havIng been established without doubt from straight line ourres, the correct set of values was established.

No study was nade of the effect of variation of the main constituent on the line intensities of the other 
elenents because of the complexity of that problem. The nothod of excess was used. This signifies that the concentretions of all the elements in the sample wore of such an amount that the effect of each on the line intensities of all the others remained constant.

The replloa grating shoved fairly acourate dispersion, and good resolution was obtalned for the lines. The determination of the end points of the lines was purely a matter of personal estination, but the aifferences of Iengths of two lines determined by different persons were in excellent agrecment.

Line mensurements were made of the corn ash spectrogram, and by reference to the operating ourves the folloving analysis was obtained ( based on lo ) :

$\begin{array}{lr}\text { oxide } & \% \\ \mathrm{~K}_{2} \mathrm{O} & 15.0 \\ \mathrm{Na}_{2} \mathrm{O} & 15.5 \\ \mathrm{heO} & 14.4 \\ \mathrm{CaO} & 2.3 \\ \mathrm{Fe}_{2} \mathrm{O}_{3} & 1.06 \\ \mathrm{P}_{2} \mathrm{O}_{5} & 24.3 \\ \mathrm{SLO}_{2} & 27.44\end{array}$

It was observed that the internal standard mothod 
and the ratio quantitative systom besed on ingo gave results. thich vere in ercellent agroement. The enalysis bosed on Cao did not agree well with those of the other nethods. Both systems are recomended por quantitativo spectral anelysis.

By use of the methods employed, of the sane times of exposure and developrent, and of Ilke conditions of preparation of stmples, it should be possible at any future time ror investigators to dotermine thege maj mineral constituents of ash saruples by means of the established operating curves. 


\section{2}


The author wishes to express his appreciation

for the ald and suggestions of Ifr. J*F.Hertweck, Dr. R. A. Lorine, and Prof. J.A. Ayers. 
114

BIBLIOGRAPHX 
1. Ballara,S.5.; Pnys. Rev., Vol.52, 253 (1937)

2. Ballard,.S.; Phys. Rev., Vol.53, 689 (1938)

3. Brode, ...; Am. Soc. leating latarials, Proc. Soc; Terting Haterials, Pt.II, Vol.35, $47-98$ (1935)

4. Brode,H.R.; Ina. Ing. Chem., Anal.Ed., 6, 157(1934)

5. Duffendack,0.S., Thonson, K.B.; Am.Soc. Testing liaterials, Proo. oc. Testine laterials, Pt.II, Vol. $36,301-9(1936)$

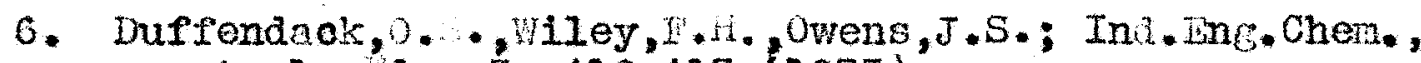
Anal. B., 7, 410-413 (1935)

7. Duffendack, 0.5., olfe, R.A.; Ind.Fng.Chem., inal.ibd., 10, 161 (1938)

8. Duffendack, S., Wolfe, R.A., Snith, R.W.; Ind. Eng. Chem. Anal. Ed., 5, 226-9 (1933)

. Estey, R.S.; "The Use of the spencer Spectroneter, Spencer Lens Company, uff 10 , New York, 1938.

10. Lwing, D.T., Vilson, H.F.,Hibbard, R.P.; Ind. Eng. Chera, Ana1. Ld., 9,410-14 (1937)

11. Yox,J.J., Levid,..J., Sm th,D.l.; ; Analyst, $\forall 01.60$, No. 708 , Tanuary, 1935.

12. ilarvey,A.; Sclence Progress, No.100, vetober, 1932.

13. Hitchen, C.5.; irans. An. Inst. Winlng Het. Eng., Februery, 1933.

14. Sull,F.A.,Steele,C.J.; N. Soc. lestine Materiale, roc. Am. Soc.Testine laterials, Pt.II, Vol.27, 284-297, (1927)

15. Lultgron, Il.; J. An. Chen. Soc., 54, 2320-8 (1932)

16. Irarence,V.; Ind. Eng. Cher., nal. La., 7.421 (1935)

17. Levis,5.J.; Chenistry and Industry, Vol.51, Mo. 13, $271-4$ (1932)

18. Menkowitch, A.; Metals ana Alloys, June,1938, 131. 
19. Milbourn,Li; J. .C.I., vol.56,205-9 (1937)

20. Nitchie,c.0.; Ind. Wng. chon., Anel. Ld., 1, I-7 (1929)

21. wens,J.S.; Ind.En;.Chom., Ana...d., 10, 64 (1938)

22. wens,J.S.; Wotals and Alloys, tanuery, 1938.

23. Kogers,L.I.; Ind. Eng.Chem., Anal.Ea., 7, 421 (1935)

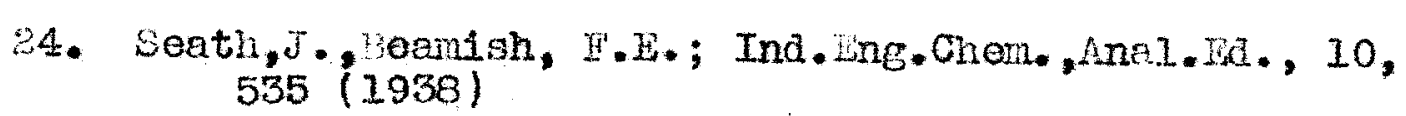

25. Shipman, H....; thesis, Iowa tate colloge, 1938.

26. Slavin, M.; Eng.Mining o., Deoember, 1033 .

27. Sullivan, f.ll.; Ind.MnE.Chen., Anal. d., 8, 398 (1936)

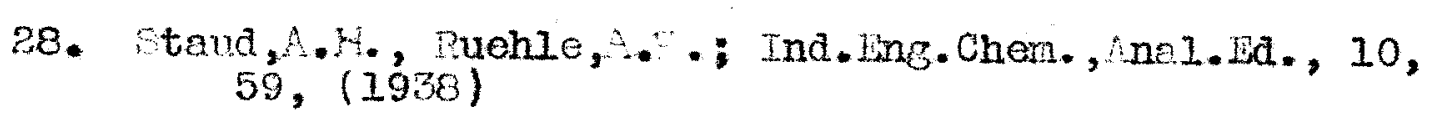

29. Thomson, K.B., Duffendack, .S.; J.Optical soc. .m., ol. $23,101-4$ (1933)

30. pourtellotte, $1 .$, Resk, 0...; Ind.Eng.Cher., nal.La., 3. $97-102 \quad 1931$

31. Thrman, J.,Simeon, F.; Frans. Opt.Soc., Vol.31, No. a, $(1929-30)$

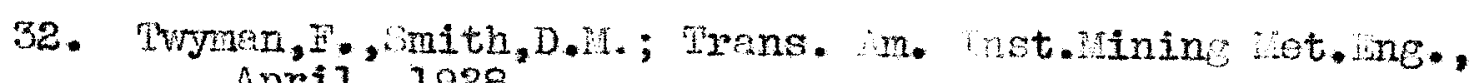
Aprii, 1928.

33. "Directions for perating the cenco cratine spectroBreph" ,Contral Seientific Conpeny.

34. "Instmuments for Spectrographic nalysis",Catalog

D-20, Rochester, ifew York, Bausch and Jomb optical company, 1958.

* Indicates a secondrry source of rerorence. 


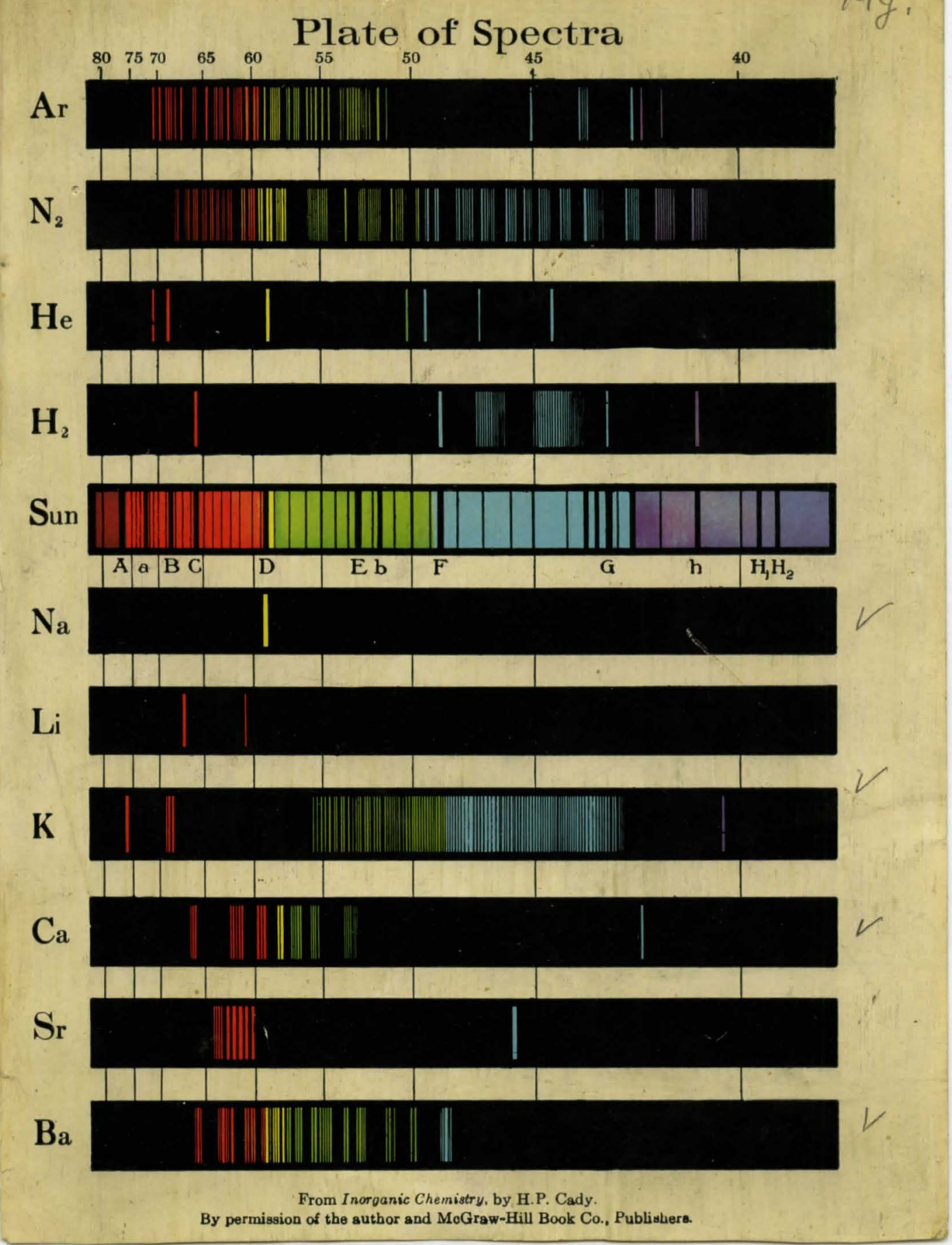

